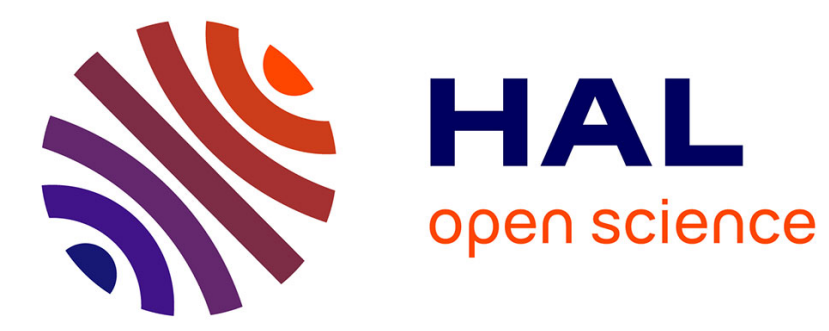

\title{
Size-dependent uptake of nitrate and ammonium as a function of light in well-mixed temperate coastal waters
}

Jean-François Maguer, Stéphane L'Helguen, Julien Caradec, Cécile Klein

\section{To cite this version:}

Jean-François Maguer, Stéphane L'Helguen, Julien Caradec, Cécile Klein. Size-dependent uptake of nitrate and ammonium as a function of light in well-mixed temperate coastal waters. Continental Shelf Research, 2011, 31 (15), pp.1620-1631. 10.1016/j.csr.2011.07.005 hal-00636263

\section{HAL Id: hal-00636263 \\ https://hal.univ-brest.fr/hal-00636263}

Submitted on 27 Oct 2011

HAL is a multi-disciplinary open access archive for the deposit and dissemination of scientific research documents, whether they are published or not. The documents may come from teaching and research institutions in France or abroad, or from public or private research centers.
L'archive ouverte pluridisciplinaire HAL, est destinée au dépôt et à la diffusion de documents scientifiques de niveau recherche, publiés ou non, émanant des établissements d'enseignement et de recherche français ou étrangers, des laboratoires publics ou privés. 
Size-dependent uptake of nitrate and ammonium as a function of light in well-mixed temperate coastal waters

Jean-François Maguer *, Stéphane L’Helguen, Julien Caradec, Cécile Klein

UMR 6539, UBO-CNRS-IRD, Laboratoire de l'Environnement MARin (LEMAR), Institut

Universitaire Européen de la Mer, Technopôle Brest Iroise, Place Nicolas Copernic, 29280

Plouzané, France

*Corresponding author.

Phone: 33298498778

Fax: 33298498698

E-mail address: maguer@univ-brest.fr (J.F. Maguer)

Keywords:

Nitrogen uptake, kinetics, light, size, mixing, coastal waters 
Abstract

The effect of light on nitrate $\left(\mathrm{NO}_{3}{ }^{-}\right)$and ammonium $\left(\mathrm{NH}_{4}{ }^{+}\right)$uptake by natural communities was investigated in relation to cell size $(<10 \mu \mathrm{m}$ and $>10 \mu \mathrm{m})$ in the well-mixed coastal waters of the English Channel. Nitrogen $(\mathrm{N})$ uptake kinetics as a function of irradiance were assessed using ${ }^{15} \mathrm{~N}$ tracer techniques, for a seasonal cycle of populations collected at $50 \%$ and 1\% light penetration depth. The nitrogen uptake responses to irradiance can be represented by the formulation used to describe the photosynthesis versus irradiance relationships and modified by the addition of a dark uptake parameter. The response curves of two size fractions of phytoplankton collected at $50 \%$ and $1 \%$ of incident light did not differ significantly, which suggested that the physiological characteristics of $\mathrm{N}$ uptake were not affected by the light intensity at which the phytoplankton assemblages were sampled. The kinetics parameters indicated that the $\mathrm{NO}_{3}{ }^{-}$uptake system was more strongly dependent on light than the $\mathrm{NH}_{4}{ }^{+}$uptake system. They also showed that $\mathrm{N}$ uptake was less limited by the light intensity in the small size fraction than it was in the large size fraction. At the mean light intensity in the water column, kinetics analysis predicted a $\mathrm{NH}_{4}{ }^{+}$uptake that was on average $1.8( \pm 0.6)$ and $2.4( \pm 1.0)$ times greater than the $\mathrm{NO}_{3}{ }^{-}$uptake, for $<10 \mu \mathrm{m}$ and $>10 \mu \mathrm{m}$ size fractions, respectively. The kinetics also predicted, at the in situ mean light intensity, that the mean ability to take up nitrogen was twice as high $(1.8 \pm 0.5)$ for the small than for the large cells when the $\mathrm{N}$ substrate was $\mathrm{NH}_{4}{ }^{+}$and more than twice as high $(2.6 \pm 1.5)$ when the substrate was $\mathrm{NO}_{3}{ }^{-}$. These results added to our understanding of the light effect on $\mathrm{N}$ uptake processes in well-mixed waters, and can largely explain the phytoplankton production, mainly regenerated and dominated by small cells, that has been observed in these waters. 


\section{Introduction}

It has been clearly established that phytoplankton growth depends on its photosynthesis capacity, as well as its nutrient uptake efficiency in environments where nutrient availability and light resource conditions are not optimal. Among its essential nutrients, nitrogen $(\mathrm{N})$ is believed to play a major role in determining the primary productivity of the ocean (Ryther and Dunstan, 1971; Goldman et al., 1979); therefore, it is essential to determine the key factors that control $\mathrm{N}$ use by phytoplankton. Traditionally, the ability of phytoplankton to uptake $\mathrm{N}$ has been explained using the nitrogen supply. The positive relationship between $\mathrm{N}$ availability and its uptake by phytoplankton is a well documented pattern (Mulholland and Lomas, 2008 and references therein). In addition to substrate effects, it is also well known that $\mathrm{N}$ uptake in both cultured and natural communities is linked to the light regime, through photosynthesis, directly or indirectly. The $\mathrm{N}$ uptake versus irradiance curves are typically hyperbolic and can be fit mathematically by a simple single Michaelis Menten function (MacIsaac and Dugdale, 1972). The relationship can also be fitted with a modification of the equation of Platt et al. (1980), which was originally developed for the light response of photosynthesis (Priscu et al., 1991). The degree of the $\mathrm{N}$ uptake dependence on light appears to be specific to the $\mathrm{N}$ substrate, in particular at low light levels and in dark areas where phytoplankton often use $\mathrm{NH}_{4}{ }^{+}$more efficiently than $\mathrm{NO}_{3}{ }^{-}$(Muggli and Smith, 1993; Kudela et al., 1997). This can be also affected by the general physiological status of the population studied. For example, Cochlan et al. (1991) have highlighted that a populations collected from the base of the euphotic zone, and therefore likely acclimated to low light, displayed much less light dependence of $\mathrm{NO}_{3}{ }^{-}$uptake than those collected in surface waters. Studies have also shown that $\mathrm{N}$ deprivation can weaken the light dependence of $\mathrm{N}$ uptake (Paasche et al., 1984, Cochlan et al. 1991; Flynn et al 1999). In addition, the degree of N-uptake dependence on 
light can also be affected by interactions between $\mathrm{N}$-uptake and cellular growth (Kudela et al. 1997, Clark et al. 2002, Flynn et al. 1999, 2002), which in turn reflects the internal reserves of photosynthetic energy and internal nitrogen pools of the cells. Numerous studies have investigated the $\mathrm{N}$ uptake light dependency by considering taxonomic groups (Harisson, 1976; Paasche et al., 1984) or isolated species (Kudela and Cochlan, 2000; Fan and Glibert, 2005). For the above reasons, most of these studies found that the response of $\mathrm{N}$ uptake as a function of light is species dependent and highly variable. This makes it difficult to infer how the degree of light dependence on $\mathrm{N}$ uptake is affected by taxonomic group or species. To our knowledge, only one study (Frenette et al., 1998) focused on N uptake as a function of cell size in addition to light, and it only considered $\mathrm{NO}_{3}{ }^{-}$as the $\mathrm{N}$ substrate.

Light has been considered a key factor controlling phytoplankton production in the wellmixed coastal waters of the English Channel (Boalch et al., 1978; Wafar et al., 1983; L’Helguen et al., 1996). In this system, the effect of light on phytoplankton dynamics has been linked to strong hydrodynamic effects induced by tidal currents and wind action. Hydrodynamics prevents the water column from becoming stratified, so that the phytoplankton cells are continuously entrained below the euphotic zone, reducing the light available to them. As a result, primary production tends to increase up to a summer maximum (Boalch et al., 1978), and is in phase with the increase of the incident light and the depth of the euphotic layer. These unusual patterns of carbon uptake formed the basis of earlier interpretations that the primary production cycle was mainly regulated by light (Wafar et al., 1983). The seasonal patterns of $\mathrm{N}$ uptake reflected the characteristics of the primary production summer maximum, and chlorophyll a specific $\mathrm{N}$ uptake has been related to incident light. These observations led L’Helguen et al. (1996) to conclude that N uptake was strongly limited by light throughout the year. It has also been suggested that the high contribution of $\mathrm{NH}_{4}{ }^{+}$to the total $\mathrm{N}$ uptake, as well as the dominance of small sizes in 
phytoplankton communities, could be controlled by physical forcing, and thus indirectly by the unusual light regime inherent in this system (Wafar et al., 2004). Although convincing, these conclusions suffered from a lack of direct measurements of $\mathrm{N}$ uptake as a function of light.

The present paper describes the kinetics of $\mathrm{NO}_{3}{ }^{-}$and $\mathrm{NH}_{4}{ }^{+}$uptake as a function of irradiance for two size fractions of phytoplankton ( $<10 \mu \mathrm{m}$ and $>10 \mu \mathrm{m}$ of size) in the well-mixed waters of the English Channel during a seasonal cycle. The scope of the work assessed the responses of phytoplankton communities to light intensity variations for different environmental conditions, in order to (i) examine the light dependence of $\mathrm{N}$ uptake, (ii) investigate the relationships between the used $\mathrm{N}$ substrate and the light regime, and (iii) evaluate the hypothesis that small and large cells differ in their $\mathrm{N}$ uptake versus light characteristics.

2. Material and Methods

\subsection{Sampling}

Experiments were conducted from January through December 2005 at a study site $\left(48^{\circ} 45^{\prime} \mathrm{N}\right.$, 357’40' 'W - mean depth: 45 m) investigated previously (Wafar et al., 1983, 2004; Le Corre et al., 1996; L’Helguen et al., 1996). Water samples for the experiment were collected during spring tide at around 8:00 a.m. local time. In each instance, water samples were obtained from three depths $(0,20$, and $40 \mathrm{~m})$ to determine the $\mathrm{NO}_{3}{ }^{-}$and $\mathrm{NH}_{4}{ }^{+}$concentrations. Samples for the $\mathrm{N}$ uptake measurements were obtained from the $50 \%$ and $1 \%$ light penetration depth, as calculated by measuring downwelling radiation with a Licor photometer. Depending on the volume needed, water was collected with 5 or 30 L PVC Niskin bottles. 


\subsection{Environmental parameters}

Vertical profiles for the temperatures and Photosynthetically Active Radiation (PAR 400-700 $\mathrm{nm}$ ) were recorded using a Seabird SBE 19 system and used to describe the vertical structure of the water column. For each occasion, the light attenuation coefficient $k$ was computed by $k=\left(\operatorname{Ln} I_{0}-\operatorname{Ln} I_{z}\right) / z$

where $z$ was the water column depth $(\mathrm{m}) ; I_{0}\left(\mu \mathrm{mol}\right.$ photons $\mathrm{m}^{-2} \mathrm{~s}^{-1}$ ) was the surface incident light, and $I_{z}\left(\mu \mathrm{mol}\right.$ photons $\left.\mathrm{m}^{-2} \mathrm{~s}^{-1}\right)$ was the light at depth $z$. The mean water column light $\left(I_{m}\right)$ was then computed from

$I_{m}=I_{0}\left(1-\exp ^{-k . z}\right) / k . z$

$\mathrm{NO}_{3}{ }^{-}$concentrations were determined using a Technicon Autoanalyseur II following the procedures of Wood et al. (1967), and $\mathrm{NH}_{4}{ }^{+}$concentrations were measured manually in triplicate using the indophenol blue method (Koroleff, 1970). The analytical precision (SE) for the $\mathrm{NO}_{3}{ }^{-}$and $\mathrm{NH}_{4}{ }^{+}$concentration measurements were \pm 0.05 and $\pm 0.02 \mu \mathrm{mol} \mathrm{L}{ }^{-1}$, respectively.

\section{3. $\mathrm{N}$ uptake versus light experiments}

The uptake rates of $\mathrm{NO}_{3}{ }^{-}$and $\mathrm{NH}_{4}{ }^{+}$were measured for two size fractions (total community and $<10 \mu \mathrm{m}$ ) using the ${ }^{15} \mathrm{~N}$ method. The sampled water was dispensed into eight acid-washed polycarbonate Nalgene bottles (2 L), and enriched with ${ }^{15} \mathrm{~N}$ tracer in the form of $\mathrm{Na}^{15} \mathrm{NO}_{3}$ or ${ }^{15} \mathrm{NH}_{4} \mathrm{Cl}$ (99 atom $\%{ }^{15} \mathrm{~N}$, CEA, France). In order to prevent any substrate limitation of the $\mathrm{N}$ uptake processes during the experiments, the ${ }^{15} \mathrm{~N}$ tracer was added so as to obtain a final concentration $20 \mu \mathrm{mol} \mathrm{L}{ }^{-1}$ for $\mathrm{NO}_{3}{ }^{-}$and $5 \mu \mathrm{mol} \mathrm{L}{ }^{-1}$ for $\mathrm{NH}_{4}{ }^{+}$. This addition does not disturb the $\mathrm{N}$ uptake processes when the ambient concentrations are sufficient to saturate the $\mathrm{N}$ uptake capacity of phytoplankton. In the other hand, it could cause an overestimation of in 
situ uptake rates if the concentrations are insufficient to satisfy the maximal uptake capability of cells. In these conditions, ${ }^{15} \mathrm{~N}$ additions could also give rise to initial high rates at the beginning of the incubation or "surge uptake" corresponding to the initial filling of internal pools with inorganic nitrogen (Conway et al., 1976). This effect and negative feedback processes as $\mathrm{N}$ pool within the cells are filled, which lead in a second step to an decrease of the $\mathrm{N}$ uptake rates, have a short duration (seconds to minutes) and have probably a low impact on the measured rates for incubation time used in the present study (see below). After inoculation, the flasks were then placed in incubators equipped with neutral-density shading screens, which simulated the following photosynthetic photon flux densities: 100, 50, 22.5, $14.5,8,3,1$, and $0 \%$ of $\mathrm{I}_{0}$. A constant temperature was maintained with a continuous flow of surface seawater. The incubations were stopped after 1 hour to minimize the cells' acclimation to a particular light level. During such incubation period, one can expected to measure assimilation rather than transport into the cell. However, as the effect of a surge uptake is not completely excluded (see above), we preferred to use the term uptake which included both processes (Flynn. 1998). Following incubation, the samples were separated into two $1 \mathrm{~L}$ aliquots. The first aliquot was pre-filtered by gentle suction ( $<50 \mathrm{~mm} \mathrm{Hg}$ ) using a 10 $\mu \mathrm{m}$ pore size polycarbonate filter. The filtrate and the second aliquot were then filtered onto pre-combusted $\left(450^{\circ} \mathrm{C}\right.$, 4h) Whatman-GF/F-filters at a pressure lower than $100 \mathrm{~mm} \mathrm{Hg}$. All GF/F-filters were oven dried $\left(60^{\circ} \mathrm{C}\right)$ for $24 \mathrm{~h}$ prior to the in-lab analysis. These filters were used to determine particulate organic nitrogen (PON) concentrations along ${ }^{15} \mathrm{~N}$ enrichments, enabling $\mathrm{NO}_{3}{ }^{-}$and $\mathrm{NH}_{4}{ }^{+}$uptake rates for the total and $<10 \mu \mathrm{m}$ size fractions to be obtained. The PON concentrations and ${ }^{15} \mathrm{~N}$ enrichments of organic matter were quantified with a mass spectrometer (Delta plus, ThermoFisher Scientific, Bremen, Germany) coupled with a C/N analyzer (Flash EA, ThermoFisher Scientific) via a type III interface. The standard deviations (SE) were $0.004 \mu \mathrm{mol} \mathrm{L}{ }^{-1}$ and 0.0001 atom \% for PON and ${ }^{15} \mathrm{~N}$ enrichment, respectively. 
The absolute $\mathrm{N}$ uptake rates $\left(\rho_{\mathrm{N}}, \mu \mathrm{mol} \mathrm{L} \mathrm{L}^{-1} \mathrm{~h}^{-1}\right)$ for the total and $<10 \mu \mathrm{m}$ size fractions were calculated from the equation in Dugdale and Wilkerson (1986), in which the PON concentration was equal to the concentration measured at the end of incubation. The rates for the $>10 \mu \mathrm{m}$ size fraction were obtained by subtracting the $<10 \mu \mathrm{m}$ size fraction rates from those for the total community. The absolute uptake rates were then expressed in term of PON specific uptake rates $\left(\mathrm{V}_{\mathrm{N}} \mathrm{h}^{-1}\right)$ by dividing the absolute $\mathrm{N}$ uptake rates by the PON concentration. Note that $\mathrm{NH}_{4}{ }^{+}$isotope dilution, which can significantly bias uptake rates, was not directly assessed in this study. However, we assumed that the effects of isotope dilution were probably small due to short incubation times (Harrison and Harris, 1986).

\subsection{Kinetic parameters and data analysis}

The response of $\mathrm{N}$ uptake as a function of irradiance was modeled by the multi-parameter formulation proposed by Platt et al. (1980), and modified by adding a positive $y$ intercept to account for dark uptake (Priscu et al., 1991):

$V_{N}=V_{\text {max }}^{\prime}\left(1-\exp ^{-a}\right) \exp ^{-b}+V_{d}$

where $V_{N}$ was the $\mathrm{N}$-specific uptake rate $\left(\mathrm{h}^{-1}\right) ; V^{\prime}{ }_{\max }\left(\mathrm{h}^{-1}\right)$ was the maximal value of $V_{N}$ in the absence of photoinhibition; $a$ equals $\alpha I / V^{\prime}{ }_{\max }$, where $\alpha$ was the initial slope of the curve; and $b$ equals $\beta I / V^{\prime}{ }_{\max }$, where $\beta$ was the slope of the photo-inhibition portion of the curve. $I$ was the irradiance ( $\mu \mathrm{mol}$ photons $\mathrm{m}^{-2} \mathrm{~s}^{-1}$ ) at which $V_{N}$ is measured, and $V_{d}$ was the dark specific uptake rate $\left(\mathrm{h}^{-1}\right)$. It was assumed that this last term was constant regardless of light intensity. Note that the values of $V^{\prime}{ }_{\max }$ referred to a portion of the light response curve and did not include the substantial dark $\mathrm{N}$ uptake (Cochlan et al., 1991). Therefore, the total maximum specific uptake rates observed $\left(V_{\max }\right)$ were obtained as $V^{\prime}{ }_{\max }+V_{d}$. The irradiance $\left(K_{L T}\right)$ at 
which the uptake rate was one-half of $V^{\prime}{ }_{\max }$ was also determined. This facilitated comparisons with previously published kinetic studies for which the $\mathrm{N}$ uptake versus irradiance curves were mathematically fit by a Michaelis-Menten type equation. The $\alpha$ parameter given by the Platt et al. equation then became equivalent to the $V^{\prime}{ }_{\max } / K_{L T}$ ratio, which is often used as an index of the phytoplankton communities’ sensitivity to nitrogen take up at low light intensities.

A Matlab $®$ iterative curve fitting procedure was used to generate the descriptive curve parameters for all kinetics. The criterion $\mathrm{r}^{2}>0.8$ was applied to determine if the curve was adjusted to the experimental data. For each experiment, an F-test was performed according to Mead and Curnow (1983) and Potvin and Lechowicz (1990) to test if the curves at 50\% and $1 \%$ of $\mathrm{I}_{0}$ were significantly different. In this test, the mean square residual obtained by fitting the equation to all data points was compared with that obtained by fitting the equation separately to data from each light depth. The acceptance of the null hypothesis, i.e., that there was no significant increase in the residual sum of squares that resulted from grouping the data, was equivalent to the absence of a significant light depth effect on the $V_{N^{-}} I$ curve response. The same test was also used to compare the $V_{N^{-}} I$ curves of $<10 \mu \mathrm{m}$ and $>10 \mu \mathrm{m}$-size fractions and those obtained for $\mathrm{NO}_{3}{ }^{-}$and $\mathrm{NH}_{4}{ }^{+}$.

Paired-sample Wilcoxon signed-rank tests were used to determine whether the difference observed between the kinetics parameters for the two size fractions and/or for the two substrates studied were statistically significant $(\mathrm{P}<0.05)$. Non-parametric tests were selected due to the small number of data sets and their non-normal distribution.

\section{Results}




\subsection{Physical and chemical setting}

The solar radiation varied from 1 to $37 \mathrm{MJ} \mathrm{m}^{-2}$ day $^{-1}$ during the seasonal cycle, with a period of high radiation (mean $\pm \mathrm{SE}: 20 \pm 7 \mathrm{MJ} \mathrm{m}^{-2}$ day $^{-1}$ ) occurring between April and August (Fig. 1(a)). The euphotic zone depth $\left(Z_{e}\right)$, defined as the depth corresponding to $1 \%$ of incident light $\left(I_{0}\right)$, was between $11 \mathrm{~m}$ and $38 \mathrm{~m}$ (Fig. 1(b)) and varied as the solar radiation. The mean light in the water-column $\left(I_{m}\right)$ ranged from 17 to $97 \mu$ mol photons $\mathrm{m}^{-2} \mathrm{~s}^{-1}$ (mean: $57 \mu \mathrm{mol}$ photons $\mathrm{m}^{-2} \mathrm{~s}^{-1}$ ) (Fig. 1(c)), which corresponded to an $\mathrm{I}_{0}$ range of 11.6-20.1\% (mean: 14.5\%). The seasonal changes in $I_{m}$ were also generally similar to those in the solar radiation, with maximum values occurring in spring-summer. The occasional transient decrease of $I_{m}$ and $Z_{e}$ observed in May and July were related to a lower penetration of light within the water column, induced by high turbidity. The increase of solar radiation with the onset of summer led to a continued warming of the water column, from $8.5^{\circ} \mathrm{C}$ in March to $15.2^{\circ} \mathrm{C}$ in August (Fig. 1(d)). Water temperatures were vertically uniform during the study period, consistent with the permanently well-mixed waters of the English Channel (Boalch et al., 1978; Wafar et al., 1983). This homogenous feature of the water column was associated with the combined effects of strong tidal currents and wind action, which together distributed the heat flow throughout the whole water column and prevented seasonal stratification.

Dissolved inorganic nitrogen (DIN) concentrations also followed seasonal trends similar to those reported in earlier studies (Wafar et al., 1983). Nitrate $\left(0.35-9.05 \mu \mathrm{mol} \mathrm{L}{ }^{-1}\right)$ was the major DIN compound throughout the year (Fig. 2). Seasonally there was slow and extended nitrate utilization during spring phytoplankton growth, and it was also present in residual concentrations (between 0.35 and $1.10 \mu \mathrm{mol} \mathrm{L}^{-1}$ ) at the end of spring and summer. Ammonium concentrations varied from 0.10 to $0.78 \mu \mathrm{mol} \mathrm{L}^{-1}$, with the spring-summer 
accumulation accounting for most of this variation (Fig. 2). No significant differences in $\mathrm{NO}_{3}{ }^{-}$ and $\mathrm{NH}_{4}{ }^{+}$concentrations between the surface and depth were observed during the year. Previous studies conducted at the same station (L’Helguen et al., 1996) indicated that ambient concentrations of about 1,0 and $0.3 \mu \mathrm{mol} \mathrm{L}{ }^{-1}$ for $\mathrm{NO}_{3}{ }^{-}$and $\mathrm{NH}_{4}{ }^{+}$respectively, were sufficient to saturate $\mathrm{N}$ uptake processes. Although not tested here, it was therefore likely that $\mathrm{NO}_{3}{ }^{-}$ uptake was independent on its availability at any time of the year, except for a brief period in late May when concentrations were at their lowest. This was also probably the case for $\mathrm{NH}_{4}{ }^{+}$ uptake for late spring to summer when phytoplankton was actively growing. On the other hand, $\mathrm{NH}_{4}{ }^{+}$uptake could be substrate dependent in winter-early spring and in autumn when $\mathrm{NH}_{4}{ }^{+}$concentrations were less than $\sim 0,3 \mu \mathrm{mol} \mathrm{L}{ }^{-1}$.

\section{2. $\mathrm{N}$ uptake versus light kinetics}

The responses curves for $\mathrm{NO}_{3}{ }^{-}$and $\mathrm{NH}_{4}{ }^{+}$uptake versus light for the two planktonic size fractions $(<10 \mu \mathrm{m}$ and $>10 \mu \mathrm{m})$, at $50 \%$ and $1 \%$ of $I_{0}$, could be described $\left(\mathrm{r}^{2}>0.8\right)$ by the modified formulation of Platt et al. (1980) in 94\% of the experiments during the springautumn period. In winter, the uptake rates did not vary significantly with light and were not correctly modeled; therefore, only data obtained between March and November are presented here (Fig. 3 and 4).

When the $\mathrm{N}$ substrate was in the form of $\mathrm{NO}_{3}{ }^{-}$, a comparison of the $V_{N^{-}} I$ curves at $50 \%$ and $1 \%$ of $I_{0}$ using the F-test led to the acceptance of the null hypothesis $(\mathrm{P}>0.05)$ in all cases. This conclusion held regardless of the size fraction, indicating that there was no significant difference between the two depths. When $\mathrm{NH}_{4}{ }^{+}$was the $\mathrm{N}$ substrate, the same result was obtained in $82 \%$ of the cases for the $<10 \mu \mathrm{m}$ size fraction, and in all cases for the $>10 \mu \mathrm{m}$ size fraction. This meant that the $V_{N}-I$ curves obtained at $50 \%$ and $1 \%$ of $I_{0}$ were generally not significantly different, and they could be described by the same $V_{N}-I$ curves. Using the F-test 
to compare the $V_{N^{-}} I$ response curves for the $<10 \mu \mathrm{m}$ and $>10 \mu \mathrm{m}$ size fractions at the two light depths led to the non-acceptance of the null hypothesis $(\mathrm{P}<0.05)$. This occurred due to the absence of a significant size fraction effect in $75 \%$ of the cases when the $\mathrm{N}$ substrate was $\mathrm{NO}_{3}{ }^{-}$, and in $79 \%$ of the cases when it was $\mathrm{NH}_{4}{ }^{+}$. Thus, the $V_{N^{-}} I$ curves obtained for the two size fractions must be analyzed independently regardless of the $\mathrm{N}$ substrate. The null hypothesis was also not accepted when comparing the $V_{N}-I$ curves for $\mathrm{NO}_{3}{ }^{-}$and $\mathrm{NH}_{4}{ }^{+}$uptake at the two light depths, in $86 \%$ of the cases for the $<10 \mu \mathrm{m}$ size fraction and in $61 \%$ of the cases for the $>10 \mu \mathrm{m}$ size fraction. This implied that the data obtained for the two substrates must be treated separately.

\subsection{Kinetic parameters of $\mathrm{N}$ uptake}

The kinetic parameters of $\mathrm{NO}_{3}{ }^{-}$and $\mathrm{NH}_{4}{ }^{+}$uptake as a function of irradiance for the two size fractions are summarized in Table 1 . Since the $V_{N}-I$ responses curves were governed by the same parameters independently of the light depth at which the phytoplankton assemblages were sampled, the presented data provided only the means of the parameters obtained at $50 \%$ and $1 \%$ of $I_{0}$.

\subsubsection{Small size fraction}

The maximum $\mathrm{NH}_{4}{ }^{+}$uptake rates $\left(V^{\prime}{ }_{\max N H 4}\right)$ for the $<10 \mu \mathrm{m}$ size fraction displayed seasonal changes (Kruskal-Wallis test, $\mathrm{X}^{2}=8.25 ; \mathrm{P}_{\text {value }}=0.02$ ), with highest values in summer. In contrast, no significant trend was seen in the maximum $\mathrm{NO}_{3}{ }^{-}$uptake rates $\left(V^{\prime}{ }_{\text {max } \mathrm{NO} 3}\right)$ throughout the year (Kruskal-Wallis test, $\mathrm{X}^{2}=1.60$; $\mathrm{P}_{\text {value }}=0.45$ ). The values of $V_{\max }^{\prime}$ for the $\mathrm{NH}_{4}{ }^{+}$uptake exceeded (Wilcoxon signed-rank test, $\mathrm{P}=0.005$ ) those obtained for the $\mathrm{NO}_{3}{ }^{-}$ uptake (Fig. 5), and were reached for irradiances $\left(E_{\left.\text {opt } \mathrm{NH}_{4}\right)}\right.$ (mean \pm SE: $288 \pm 94 \mu \mathrm{mol}$ photons $\mathrm{m}^{-2} \mathrm{~s}^{-1} ; 29 \pm 13 \%$ of $I_{0}$ ) that were significantly lower (Wilcoxon signed-rank test, $\mathrm{P}=$ 
0.006) than the corresponding $E_{\text {opt }}$ for $\mathrm{NO}_{3}{ }^{-}$(mean $\pm \mathrm{SE}: 583 \pm 268 \mu \mathrm{mol}$ photons $\mathrm{m}^{-2} \mathrm{~s}^{-1} ; 56 \pm$ 25\% of $I_{0}$ ) (Fig. 5). Another difference between the $\mathrm{NH}_{4}{ }^{+}$and $\mathrm{NO}_{3}{ }^{-}$uptake for this size community was apparent at low irradiances, and was reflected by $K_{L T}$ values of the $\mathrm{NH}_{4}{ }^{+}$ uptake (mean \pm SE: $43 \pm 15 \mu$ mol photons $\mathrm{m}^{-2} \mathrm{~s}^{-1}$ ) that were less (Wilcoxon signed-rank test, $\mathrm{P}=0.002$ ) than those of the $\mathrm{NO}_{3}{ }^{-}$uptake (mean $\pm \mathrm{SE}: 98 \pm 44 \mu \mathrm{mol}$ photons $\mathrm{m}^{-2} \mathrm{~s}^{-1}$ ) (Fig. 5 ). On average, the $K_{L T}$ values represented $4.3 \pm 1.8 \%$ of $I_{0}$ for $\mathrm{NH}_{4}{ }^{+}$uptake, and $10.3 \pm 4.6 \%$ of $I_{0}$ for $\mathrm{NO}_{3}{ }^{-}$uptake. Dark uptake accounted for a substantial portion of the total maximum uptake $\left(V_{\max }\right)$, ranging from 15 to $57 \%$ (mean \pm SE: $42 \pm 13 \%$ ) and from 39 to $76 \%$ (mean \pm SE: $59 \pm 13 \%$ ) of $V_{\text {max }}$, for $\mathrm{NH}_{4}{ }^{+}$and $\mathrm{NO}_{3}{ }^{-}$uptake respectively. Note that the $V_{d}$ values for the $\mathrm{NH}_{4}{ }^{+}$uptake were larger than those for the $\mathrm{NO}_{3}{ }^{-}$uptake (Fig. 5). The $\mathrm{N}$ uptake was generally only slightly photo-inhibited at high irradiances (Fig. 3 and 4$)$, with a mean reduction ( \pm SE) compared to $V_{\max }$ of $13.2 \pm 6.3 \%$ and $9.5 \% \pm 11.0 \%$ for the $\mathrm{NH}_{4}{ }^{+}$and $\mathrm{NO}_{3}{ }^{-}$uptake, respectively. No significant difference (Wilcoxon signed-rank test, $\mathrm{P}=0.117$ ) was observed in the photo-inhibition effect between the $\mathrm{NH}_{4}{ }^{+}$and $\mathrm{NO}_{3}{ }^{-}$uptakes.

\subsubsection{Large size fraction}

The maximum uptake rates $\left(V_{\text {max }}\right.$ ) of $\mathrm{NH}_{4}{ }^{+}$for the $>10 \mu$ m size fraction, as for the $<10 \mu \mathrm{m}$ size fraction, varied markedly between the seasons (Kruskal-Wallis test, $\mathrm{X}^{2}=5.25 ; \mathrm{P}_{\text {value }}=$ 0.05). This was in contrast to the $\mathrm{NO}_{3}{ }^{-}$rates (Kruskal-Wallis test, $\mathrm{X}^{2}=0.04 ; \mathrm{P}_{\text {value }}=0.98$ ). The values of $V_{\text {max }}^{\prime}$ for the $\mathrm{NH}_{4}{ }^{+}$uptake were generally higher than those for the $\mathrm{NO}_{3}{ }^{-}$uptake (Fig. 6), although the differences were not significant (Wilcoxon signed-rank test, $\mathrm{P}=0.117$ ). The $E_{\text {opt }}$ values were consistently lower (Wilcoxon signed-rank test, $\mathrm{P}=0.007$ ) for the $\mathrm{NH}_{4}{ }^{+}$ uptake (mean $\pm \mathrm{SE}: 289 \pm 81 \mu \mathrm{mol}$ photons $\mathrm{m}^{-2} \mathrm{~s}^{-1}$; $35 \pm 25 \%$ of $\mathrm{I}_{0}$ ) than for the $\mathrm{NO}_{3}{ }^{-}$uptake (mean \pm SE: $619 \pm 294 \mu$ mol photons $\mathrm{m}^{-2} \mathrm{~s}^{-1} ; 57 \pm 27 \%$ of $\mathrm{I}_{0}$ ) (Fig. 6). The $K_{L T}$ values for $\mathrm{NH}_{4}{ }^{+}$(mean $\pm \mathrm{SE}: 48 \pm 19 \mu \mathrm{mol}$ photons $\mathrm{m}^{-2} \mathrm{~s}^{-1} ; 4.3 \pm 1.7 \%$ of $\mathrm{I}_{0}$ ) were also significantly less 
(Wilcoxon signed-rank test, $\mathrm{P}=0.005)$ than those found for $\mathrm{NO}_{3}{ }^{-}$(mean $\pm \mathrm{SE}: 132 \pm 96 \mu \mathrm{mol}$ photons $\mathrm{m}^{-2} \mathrm{~s}^{-1} ; 12.3 \pm 8.7 \%$ of $\mathrm{I}_{0}$ ) (Fig. 6), indicating a lesser dependence on light for the $\mathrm{NH}_{4}{ }^{+}$uptake system. This lesser dependence was likewise obvious in the dark uptake rates, as the $V_{d}$ values for the $\mathrm{NH}_{4}{ }^{+}$uptake were relatively high (Wilcoxon signed-rank test, $\mathrm{P}=0.005$ ) compared with those of the $\mathrm{NO}_{3}{ }^{-}$uptake (Fig. 6). In addition, the dark uptake contribution to the total maximum uptake was generally higher for $\mathrm{NH}_{4}{ }^{+}$(mean $\pm \mathrm{SE}: 33 \pm 17 \%$; range: 12 $74 \%)$ than for $\mathrm{NO}_{3}{ }^{-}$(mean $\pm \mathrm{SE}: 24 \pm 12 \%$; range: $\left.0-45 \%\right)$. In general, photo-inhibition occurred at high irradiances for the two $\mathrm{N}$ substrates (Figs. 3 and 4). At $100 \%$ of $I_{0}$, the reduction of the $\mathrm{N}$ uptake compared to $V_{\max }$ was on average ( $\pm \mathrm{SE}$ ) $18.7 \pm 9.9 \%$ for $\mathrm{NH}_{4}{ }^{+}$and $19.2 \pm 20.3 \%$ for $\mathrm{NO}_{3}{ }^{-}$

\section{Discussion}

\subsection{Light dependence of $\mathrm{N}$ uptake}

The lack of significant differences between the $V_{N^{-}} I$ curves of the phytoplankton populations collected at $50 \%$ and $1 \%$ of $I_{0}$, both for the $<10 \mu \mathrm{m}$ and $>10 \mu \mathrm{m}$ size fractions, indicated that the phytoplankton communities' response to light variations was independent of the light depth at which the cells were sampled. This suggested that the phytoplankton's physiological properties for $\mathrm{N}$ uptake were similar regardless of the water column depth. This situation can occur in well-mixed waters where the cells were exposed to temporal and spatial variations in light intensity, if the vertical mixing which displaced the algal cells to different levels of light within the water column took place on smaller time scales than those for photo acclimation processes (Lewis et al., 1984). Under these conditions, the cells under exposure to light could not adjust their physiological characteristics to the light intensity; they were acclimated to continuously changing light conditions ranging from darkness to saturated light values. Thus, 
the prevailing light available for $\mathrm{N}$ uptake was not that at a particular stratum of the euphotic zone, but rather was the mean light $\left(I_{m}\right)$ within the entire column. For the $<10 \mu \mathrm{m}$ sizefraction, the $I_{m}$ values were significantly lower than the $E_{\text {opt }}$ values, accounting for not more than $12 \pm 8 \%$ of $E_{\text {opt }}$ (range: 4 - 29\%) when the $\mathrm{N}$ substrate was $\mathrm{NO}_{3}{ }^{-}$, and only $22 \pm 13 \%$ (range: 5 - 58\%) when the $\mathrm{N}$ substrate was $\mathrm{NH}_{4}{ }^{+}$(Fig. 7). A comparison of $I_{m}$ and $E_{\text {opt }}$ values for the $>10 \mu \mathrm{m}$ size fraction showed the same trend (Fig. 7), with $I_{m}$ values corresponding to $12 \pm 8 \%$ (range: $4-21 \%$ ) and $28 \pm 22 \%$ (range: $6-80 \%$ ) of $E_{\text {opt }}$ for $\mathrm{NO}_{3}{ }^{-}$and $\mathrm{NH}_{4}{ }^{+}$, respectively.

The $E_{\text {opt }}$ values for the two size fractions and for the two $\mathrm{N}$ substrates fell within the range of reported values from previous field studies. They were of the same order as those found by Pennock (1987) for $\mathrm{NO}_{3}{ }^{-}\left(60-569 \mu \mathrm{mol}\right.$ photons $\left.\mathrm{m}^{-2} \mathrm{~s}^{-1}\right)$ and $\mathrm{NH}_{4}{ }^{+}(49-375 \mu \mathrm{mol}$ photons $\mathrm{m}^{-2} \mathrm{~s}^{-1}$ ) in the Delaware estuary during a seasonal cycle. This range of values has also been reported by Cabrita et al. (1999) in the Targus estuary (400 - $900 \mu \mathrm{mol}$ photons $\mathrm{m}^{-2} \mathrm{~s}^{-1}$ ), and by Kudela and Cochlan (2000) at Newport Beach in southern California (400 - $500 \mu \mathrm{mol}$ photons $\mathrm{m}^{-2} \mathrm{~s}^{-1}$ ). The low $I_{m} / E_{\text {opt }}$ ratios measured in the coastal waters of the English Channel thus should not have indicated particular high values of $E_{\text {opt }}$, corresponding to the distinct physiological properties of phytoplankton communities. Rather, they referred to the low mean light available ( $<100 \mu \mathrm{mol}$ photons $\left.\mathrm{m}^{-2} \mathrm{~s}^{-1}\right)$ compared to $E_{\text {opt }}$. To investigate the real effect of the ambient light intensity, the $\mathrm{N}$ uptake rates at $I_{m}$ were calculated for $I_{m}\left(V_{I m}\right)$ using the kinetics parameters of the $V_{N^{-}} I$ curves, and then they were compared with those obtained for $E_{\text {opt }}\left(V_{\max }\right)$. For all data, the $V_{I m}$ values were generally well below the $V_{\max }$ values (Fig. 8), with a mean $V_{\text {Im }} / V_{\text {max }}$ ratio of $0.7 \pm 0.1$ for $\mathrm{NH}_{4}{ }^{+}$and $0.5 \pm 0.2$ for $\mathrm{NO}_{3}{ }^{-}$. These results clearly demonstrated the strong control of $\mathrm{N}$ uptake by light, even in summer when the solar radiation is maximal. These results support the hypothesis previously advanced, that the $\mathrm{N}$ uptake, as the primary production (Wafar et al. 1983), was mainly regulated by light over the year in the 
well-mixed coastal waters of English Channel (L’Helguen et al., 1996). Low light available, caused by continual mixing, could also have explained the lower $\mathrm{N}$ uptake rates measured in these waters compared to rates in other coastal waters (L’Helguen et al., 1996).

\subsection{Significant dark $N$ uptake}

Our results emphasized a significant dark $\mathrm{N}$ uptake, both for the $\mathrm{N}$ substrates and for the size fractions examined. This was not unexpected and was consistent with the findings from a wide variety of environments, i.e., that unlike photosynthetic $\mathrm{C}$ fixation, the $\mathrm{N}$ uptake process was not generally strictly light dependent (Dortch and Maske, 1982; Harrison et al., 1990; Cochlan et al., 1991; Kudela and Cochlan, 2000; Riegman et al., 2000; Fan and Glibert, 2005). Dark N uptake could be related to intermediate metabolic pathways which can provide an alternative energy source for phytoplankton cells to take up nitrogen in the absence of light (Priscu, 1984). However, the ability of phytoplankton to take up $\mathrm{NO}_{3}{ }^{-}$and $\mathrm{NH}_{4}{ }^{+}$in darkness showed a high variability which may result from a number of factors. First, the dark N uptake rates appeared to differ among specific groups such as diatoms and dinoflagellates (Cochlan et al., 1991; Chang and McClean, 1999; Clark et al., 2002; Lim et al., 2006). The ability to perform dark $\mathrm{N}$ uptake also depended on the physiological state of the cells, and the enhancement of dark $\mathrm{N}$ uptake relative to total $\mathrm{N}$ uptake has been suggestive of $\mathrm{N}$ deprivation (Harrison, 1976; Paasche et al., 1984; Kanda et al., 1989; Rigano et al., 1990; Smith et al., 1992). For example, Paasche et al. (1984) showed in culture that Gyrodinium aureolum did not up take $\mathrm{NO}_{3}{ }^{-}$in the dark under $\mathrm{N}$-replete growth conditions; however, when the culture was $\mathrm{N}$ starved, the dark uptake represented $50 \%$ of the light uptake. $\mathrm{N}$ deficiency of the cells could explain, at least for a part, the high dark uptake for $\mathrm{NH}_{4}{ }^{+}$during some periods of the year, but not that for $\mathrm{NO}_{3}{ }^{-}$. Alternatively, a substantial fraction of the measured dark $\mathrm{N}$ uptake could be ascribed to heterotrophic bacteria, since Whatman-GF/F-filters used to collect PON 
do not discriminate completely between bacteria and phytoplankton (Lee and Fuhrman, 1987). Laws et al. (1985) concluded that the contribution of bacteria to the $\mathrm{N}$ uptake accounted for at least 50 to $75 \%$ of total microbial $\mathrm{N}$ uptake in the coastal waters of the Hawaiian Islands. During the US JGOFS North Atlantic Bloom process uptake, Kirchman et al. (1994) estimated that 22 - 39\% of $\mathrm{NH}_{4}{ }^{+}$uptake was due to bacteria. Comparable bacteria data were not available for the present study. Nonetheless, it has been shown previously at the same station that the $\mathrm{N}$ uptake by the $<1 \mu \mathrm{m}$ size fraction, in which more than $70 \%$ of the heterotrophic bacteria were enumerated (L'Helguen et al., 2005), constituted less than $10 \%$ of the total $\mathrm{N}$ uptake, with mostly autotrophic $\mathrm{N}$ uptake (Wafar et al., 2004). Hence, the proportion of dark uptake involving the non-photosynthetic organisms was probably reduced. Finally, with waters in which dynamic processes expose the algal cells to fluctuations in light intensity, from saturated light energy at the surface to darkness at depth, it is likely that a strong ability to take up nitrogen in darkness may be necessary for phytoplankton communities to acquire and use resources for their growth and maintenance. The relatively high contribution of dark uptake to total uptake could be related to an ecological adaptation strategy due to the low light resulting from strong vertical mixing of the water column (Richardson et al., 1983; Huisman and Weissing, 1994; Cullen and MacIntyre, 1998; Moore et al., 2006). This view was supported by the model of Litchman et al. (2004), in which species or taxonomic groups that maintain high uptake rates in darkness or low light have a competitive advantage under low light regimes such as those encountered in deep mixed systems.

\section{3. $\mathrm{N}$ uptake as a function of light and $\mathrm{N}$ substrate}

Kinetics parameters showed that the $\mathrm{NO}_{3}{ }^{-}$uptake system appeared more light-dependent than the $\mathrm{NH}_{4}{ }^{+}$uptake system. This was initially supported by the irradiance $\left(E_{\text {opt }}\right)$ needed to reach 


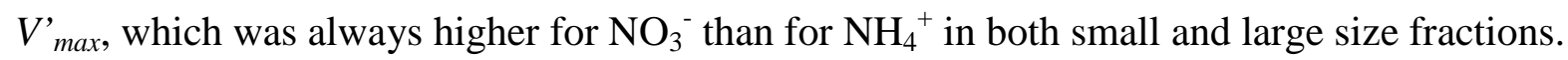
As suggested by other experimental studies (Kudela et al., 1997; Mulholland et al., 1999; Clark et al., 2002), the fact that the $V_{d}$ values were generally lower for $\mathrm{NO}_{3}{ }^{-}$uptake than for $\mathrm{NH}_{4}{ }^{+}$uptake also indicated a stronger dependence of $\mathrm{NO}_{3}{ }^{-}$uptake on light. The close coupling between the $\mathrm{NO}_{3}{ }^{-}$uptake process and light is equally reflected in the $K_{L T}$ values, with an average ( $\pm \mathrm{SE}) \mathrm{K}_{\mathrm{LT} \mathrm{NO}} / K_{\mathrm{LT} \text { NH4 }}$ ratio of $2.4( \pm 1.1)$ for the $<10 \mu \mathrm{m}$ size fraction and $3.1( \pm$ 1.8) for the $>10 \mu \mathrm{m}$ size fraction. Similarly, $K_{L T \text { NO3 }}$ values double those of $\mathrm{NH}_{4}{ }^{+}$were reported for natural phytoplankton assemblages in the Indian Sector of the Southern Ocean (Slawyk, 1979). The same patterns were observed in the Tagus estuary (Cabrita et al., 1999) and in the Auke Bay (Kanda et al., 1989). Muggli and Smith (1993) found greater differences between $K_{L T}$ values for $\mathrm{NO}_{3}{ }^{-}$and $\mathrm{NH}_{4}{ }^{+}$uptake $\left(K_{L T \text { NO3 }} / K_{L T ~ N H 4} \sim 5\right)$ in the Greenland Sea during early spring. The effect of low irradiances on the $\mathrm{N}$ substrate dependent uptake can also be expressed by comparing the $V^{\prime}{ }_{\max } / K_{L T}$ ratios for $\mathrm{NO}_{3}{ }^{-}$and $\mathrm{NH}_{4}{ }^{+}$. These ratios are always lower for $\mathrm{NO}_{3}{ }^{-}$uptake than for $\mathrm{NH}_{4}{ }^{+}$uptake, both for small and large size fractions, showing that $\mathrm{NO}_{3}{ }^{-}$uptake is substantially less sensitive at low irradiances than $\mathrm{NH}_{4}{ }^{+}$uptake. This difference between the response of $\mathrm{NO}_{3}{ }^{-}$and $\mathrm{NH}_{4}{ }^{+}$uptake to light might be an indication of the large amount of photosynthetically derived energy required for the translocation of $\mathrm{NO}_{3}{ }^{-}$across the cell membrane (Falkowski and Stone, 1975), as well as the enzymatic reduction process of $\mathrm{NO}_{3}{ }^{-}$to $\mathrm{NH}_{4}{ }^{+}$(Syrett, 1981). As a consequence, low light conditions such as those that prevailed in the well-mixed waters of the English Channel, were not conducive to the efficient utilization of $\mathrm{NO}_{3}{ }^{-}$compared to $\mathrm{NH}_{4}{ }^{+}$. At the ambient light intensity

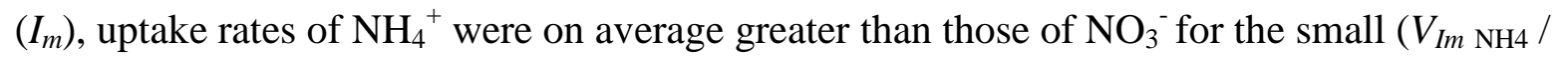
$\left.V_{I m ~ N O 3}=1.8 \pm 0.6\right)$ and large $\left(V_{I m ~ N H 4} / V_{I m ~ N O 3}=2.4 \pm 1.0\right)$ size fractions (Fig. 9). Thus, low light conditions in this system resulting from vertical mixing may have been one of the reasons that nitrogen taken up by the phytoplankton was mainly in the form of $\mathrm{NH}_{4}{ }^{+}$. This 
particular feature may have accounted for the dominant regenerated production characteristic of the well-mixed waters of the English Channel (Maguer et al., 1998), which was first related to an intense regeneration by the microheterotrophs throughout the year, and also to the continuous injection of regenerated products into the euphotic zone by vertical mixing (Le Corre et al., 1996). In addition, the large contribution of $\mathrm{NH}_{4}{ }^{+}$to the phytoplankton nutrition in this system resulted in the inhibition effect of ammonium on $\mathrm{NO}_{3}{ }^{-}$uptake, in particular during spring-summer when ammonium concentrations were sufficiently high to exert a sustained reduction of $\mathrm{NO}_{3}{ }^{-}$uptake (L’Helguen et al., 1996).

\section{4. $\mathrm{N}$ uptake as a function of light and cells size}

The response of $\mathrm{N}$ uptake to irradiance also varied with cell size, as observed in the differences between the $V_{N}-I$ curves for the $<10 \mu \mathrm{m}$ and $>10 \mu \mathrm{m}$ size fractions (Figs. 3 and 4 ). This size effect was highlighted for the $\mathrm{NO}_{3}{ }^{-}$uptake, with consistently higher $V^{\prime}{ }_{\text {max }}$ values (Wilcoxon signed-rank test, $\mathrm{P}=0.041$ ) in the $>10 \mu \mathrm{m}$ than the $<10 \mu \mathrm{m}$ size fraction. This could reflect their larger specific storage volume relative to their biomass (Stolte and Riegman. 1995). No significant difference (Wilcoxon signed-rank test, $P=0.575$ ) was apparent in the $K_{L T}$ values for this compound between the size fractions. Thus, the differences in $V^{\prime}{ }_{\max }$ values also led to $V^{\prime}{ }_{\max } / K_{L T}$ ratios significantly higher (Wilcoxon signed-rank test, $\mathrm{P}$ $=0.033$ ) in the $>10 \mu \mathrm{m}$ than in the $<10 \mu \mathrm{m}$ size fraction, suggesting a more pronounced sensitivity of the $\mathrm{NO}_{3}{ }^{-}$uptake process to light with the largest cells. This result agreed with the findings of Frenette et al. (1998) on the natural phytoplankton communities of Lake Biwa, that emphasized for $\mathrm{NO}_{3}{ }^{-}$uptake $V^{\prime}{ }_{\text {max }}$ values two times higher, and $\alpha$ values an order of magnitude higher, for the large cells than for the small ones. These authors also showed that larger cells may achieve a higher biomass $\mathrm{C}$ increment per unit of $\mathrm{NO}_{3}{ }^{-}$taken up. The greater sensitivity of the large cells' $\mathrm{NO}_{3}{ }^{-}$uptake process to light may then be a strong selective 
advantage of large cells over small cells under increased light conditions, even more so as their ability to store $\mathrm{NO}_{3}{ }^{-}$can be more pronounced (Stolte and Riegman, 1995). On the other hand, the $K_{L T}$ and $V^{\prime}{ }_{\text {max }}$ values for $\mathrm{NH}_{4}{ }^{+}$uptake showed no significant difference (Wilcoxon signed-rank test, $\mathrm{P}>0.05$ ) between the size fractions, which clearly demonstrated that the response of $\mathrm{NH}_{4}{ }^{+}$uptake to irradiance, unlike that of $\mathrm{NO}_{3}{ }^{-}$uptake, did not depend on the size of the cells. These distinct responses of the phytoplankton communities to light supported the classic partitioning of $\mathrm{N}$ uptake between size fractions. In N-replete waters, this partitioning predicts an increase of $\mathrm{NO}_{3}{ }^{-}$uptake by large size fractions at the onset of stratification, due to increasing irradiance. Such situations are usually reported at the early spring in coastal waters and on continental shelves (Kanda et al., 1989; Dauchez et al., 1996; Tremblay et al., 2000). For example, Dauchez et al. (1996) reported that between 60 and $90 \%$ of $\mathrm{NO}_{3}{ }^{-}$uptake was due to large cells during the spring bloom on the Scotian Shelf. A dominance of large cells in $\mathrm{NO}_{3}{ }^{-}$uptake has also been reported in near shore waters influenced by freshwater runoff, consequent to an $\mathrm{NO}_{3}{ }^{-}$enrichment of surface waters (Furnas, 1983; Wilkerson et al., 2000) and also to haline stratification of the water column which confers favorable light conditions for species growth (Maguer et al., 2009). As previously reported in the Ushant front (Le Corre et al., 1993), a greater contribution of the large cells to $\mathrm{NO}_{3}{ }^{-}$uptake was also associated with the stratified side of tidal fronts after a spring tide, when $\mathrm{NO}_{3}{ }^{-}$concentrations and ambient light intensity were optimal.

The cell size effect on $\mathrm{N}$ uptake was also expressed in kinetic parameters by a dark $\mathrm{N}$ uptake that was significantly higher in the $<10 \mu \mathrm{m}$ than in the $>10 \mu \mathrm{m}$ size fraction, for both $\mathrm{NO}_{3}{ }^{-}$ (Wilcoxon signed-rank test, $\mathrm{P}=0.003$ ) and $\mathrm{NH}_{4}{ }^{+}$(Wilcoxon signed-rank test, $\mathrm{P}=0.005$ ). This suggested a size specificity in the ability of phytoplankton communities to take up nitrogen in the absence of light. As a consequence, in ambient light conditions $\left(I_{m}\right)$, the ability of the $<10$ $\mu \mathrm{m}$ size fraction in taking up $\mathrm{NO}_{3}{ }^{-}$was more than twice (mean $\pm \mathrm{SE}=2.5 \pm 1.5$ ) that of the 
$>10 \mu \mathrm{m}$ size fraction, despite the greatest sensitivity of the large cells to take up $\mathrm{NO}_{3}{ }^{-}$at light. Also, the ability of the $<10 \mu \mathrm{m}$ size fraction was about twice as high (mean $\pm \mathrm{SE}=1.8 \pm 0.5$ ) than that of the $>10 \mu \mathrm{m}$ size fraction when the substrate was $\mathrm{NH}_{4}{ }^{+}$(Fig. 10). It was thus likely that the low light conditions that prevailed in the well-mixed waters of the English Channel could largely explain the dominant contribution of the small cells in $\mathrm{N}$ uptake (L'Helguen et al., 1996). The potential limitation of $\mathrm{NH}_{4}{ }^{+}$concentrations during some periods of the year whereas $\mathrm{NO}_{3}{ }^{-}$was saturating could also be a favorable condition for the dominance of small cells in $\mathrm{N}$ uptake. Indeed, relatively low levels of $\mathrm{NH}_{4}{ }^{+}$can be expected to be less disadvantageous for the small than for the large cells due to their higher affinity for this substrate (Chisholm, 1992). In addition, $\mathrm{NO}_{3}{ }^{-}$uptake was proved to be more sensitive to the inhibition effect of ammonium in the small than in the large cells (L'Helguen et al 2008). This could give an advantage to small cells for the $\mathrm{NO}_{3}{ }^{-}$uptake when $\mathrm{NH}_{4}{ }^{+}$was at low concentrations.

\section{Conclusions}

In the coastal waters of the western English Channel, the vertical mixing of the water column induced by strong tidal currents continuously entrains the phytoplankton cells below the euphotic zone, reducing the light available to them. As a consequence, light is the main factor limiting the primary production in this system. Our results demonstrated that $\mathrm{N}$ uptake was only mainly regulated by the low light available during the year. The kinetic parameters of $\mathrm{V}_{\mathrm{N}}-\mathrm{I}$ curves showed that low light conditions were unfavorable both to $\mathrm{NO}_{3}{ }^{-}$uptake and to an efficient uptake of nitrogen by the largest cells. In other words, the low light available to phytoplankton in the well-mixed waters of the English Channel was proven to be one of 
reasons why primary production was mainly regenerated and was dominated by small size fractions.

The mean light level available to cells in well-mixed waters is affected by the surface incident light and by the ratios between the depth of the mixed layer $(\mathrm{Zm})$ and that of the euphotic layer $(Z e)$. One can therefore expect in this type of ecosystem that larger $Z m / Z e$ ratios than that of the study site (mean 1.9) would increase the limiting light effect and the dominance of small cells in $\mathrm{N}$ uptake. Conversely, smaller ratios could lead to a less marked limiting light effect that could further promote $\mathrm{NO}_{3}$ uptake by large cells. In a general manner, our results suggest that light conditions resulting from vertical mixing (and the $\mathrm{Zm} / \mathrm{Ze}$ ratios) could determine the nature of production (new vs regenerated) for the total phytoplankton community as well as the trophic structure of the phytoplankton community.

\section{Acknowledgements}

We thank the captain and other crew members of R/V Mysis for their support at sea. We also wish to thank San Francisco Edit for editing and polishing the manuscript

\section{References}

Boalch, G.T., Harbour, D.S., Butler, E.I., 1978. Seasonal phytoplankton production in the Western English Channel 1964-1974. Journal of the Marine Biological Association of the United Kingdom 58, 943-953. 
Cabrita, M.T., Catarino, F., Slawyk, G., 1999. Interactions of light, temperature and inorganic nitrogen in controlling planktonic nitrogen utilization in the Tagus Estuary. Aquatic Ecology, 33, 251-261.

Chang, F.H., McClean, M., 1999. Growth responses of Alexandrium minutum (Dinophyceae) as a function of three different nitrogen sources and irradiance. New Zealand Journal of Marine and Freshwater Research, 31, 1-7.

Chisholm, S.W., 1992. Phytoplankton size. In Falkowski, P.G., Woodhead, A.D. (Eds.), Primary productivity and biogeochemical cycles in the sea, Plenum Press, New York, pp. 213-237

Clark, D.R., Flynn, K.J., Owens, N.J.P., 2002. The large capacity for dark nitrate-assimilation in diatoms may overcome nitrate limitation of growth. New Phytologist, 155, 101-108.

Cochlan, W.P., Price, N.M., Harrison, P.J., 1991. Effects of irradiance on nitrogen uptake by phytoplankton: comparison of frontal and stratified communities. Marine Ecology Progress Series, 69, 103-116.

Conway, H.L., Harrison, P.J., Davis, C. 1976. Marine diatoms grown in chemostats under silicate or ammonium limitation. 11. Transient response of Skeletonema costatum to single addition of the limiting nutrient. Marine Biology, 35, 187-199. 
Cullen, J.J., MacIntyre, J.G., 1998. Behaviour, physiology and the niche of depth-regulating phytoplankton. In: Anderson, D.M., Cembella A.D., Hallegraeff G.M. (Eds.), Physiological ecology of harmful algal blooms, Springer-Verlag, pp. 559-580.

Dauchez, S., Legendre, L., Fortier, L., Levasseur, M., 1996. Nitrate uptake by sizefractionated phytoplankton on the Scotian Shelf (Northwest Atlantic): Spatial and temporal variability. Journal of Plankton Research, 18, 4, 577-595.

Dortch, Q., Maske, H., 1982. Dark uptake of nitrate and nitrate reductase activity of a red-tide population of Peru. Marine Ecology Progress Series, 9, 299-303.

Dugdale, R.C., Wilkerson, F.P., 1986. The use of ${ }^{15} \mathrm{~N}$ to measure nitrogen uptake in eutrophic oceans: experimental considerations. Limnology and Oceanography, 31, 4, 673-689.

Falkowski, P.G., Stone, D.P., 1975. Nitrate uptake in marine phytoplankton: energy sources and the interaction with carbon fixation. Marine Biology, 32, 77-84.

Fan, C., Glibert, P.M., 2005. Effect of light on nitrogen and carbon uptake during a Prorocentrum minimum bloom. Harmful Algae, 629-641.

Flynn, K.J., 1998. Estimation of kinetic parameters for the transport of nitrate and ammonium into marine phytoplankton. Marine Ecology Progress Series, 169, 13-28. 
Flynn, K.J., Clark, D.R., Owens, N.P.J., 2002. Modelling suggests that optimization of dark nitrogen-assimilation need not be a critical selective feature in phytoplankton. New Phytologist, 155, 109-119.

Flynn, K.J., Page, S., Wood, G., Hipkin, C. R., 1999. Variations in the maximum transport rates for ammonium and nitrate in the prymnesiophyte Emiliania huxleyi and the raphidophyte Heterosigma carterae. Journal of Plankton Research, 21, 2, 355-371.

Frenette, J.J., Vincent, W.F., Legendre, L., 1998. Size-dependent C:N uptake by phytoplankton as a function of irradiance. Limnology and Oceanography, 43, 6, 1362-1368.

Furnas, M.L., 1983. Nitrogen dynamics in the lower Narragansett Bay, Rhode Island. IUptake by size-fractionated phytoplankton populations. Journal of Plankton Research, 5, 657676.

Goldman, J.C., McCarthy, J.J., Peavey, D.G., 1979. Growth rate influence on the composition of phytoplankton in oceanic waters. Nature, 279, 210-215.

Harrison, W.G., 1976. Nitrate metabolism of the red tide dinoflagellate Gonyaulax polyedra. Journal of Experimental Microbiology Biology and Ecology, 21, 199-209.

Harrison, W.G., Cota, G.F., Smith, R.E.H., 1990. Nitrogen utilization in ice algal communities of Barrow strait, Northwest Territories, Canada. Marine Ecology Progress Series, 67, 275-283. 
Harrison, W.G., Harris, L.R., 1986. Isotope dilution and its effects on measurements of nitrogen and phosphorus uptake by oceanic microplankton. Marine Ecology Progress Series, 27, 253-261.

Huisman, J., Weissing, F.J., 1994. Light-limited growth and competition for light in wellmixed aquatic environments: an elementary model. Ecology, 75, 2, 507-520.

Kanda, J., Ziemann, D.A., Conquest, L.D., Bienfang, P.K., 1989. Light dependency of nitrate uptake by phytoplankton over the spring bloom in Auke Bay, Alaska. Marine Biology, 103, 563-569.

Kirchman, D.L., Ducklow, H.W., McCarthy, J.J., Garside, C., 1994. Biomass of nitrogen uptake by heterotrophic bacteria during the spring phytoplankton bloom in the North Atlantic Ocean. Deep Sea Research, 41, 879-895.

Koroleff, F., 1970. Direct determination of ammonia in natural waters as indophenols blue. International Council for the Exploration of the Sea (ICES), revised version of ICES paper C.M. 1969/C:9, Interlaboratory Report 3, 19-22

Kudela, R., Cochlan, W.P., 2000. Nitrogen and carbon uptake kinetics and the influence of irradiance for a red tide bloom off Southern California. Aquatic Microbial Ecology, 21, 31-47.

Kudela, R., Cochlan, W.P., Dugdale, R.C., 1997. Carbon and nitrogen uptake response to light by phytoplankton during an upwelling event. Journal of Plankton Research, 19, 5, 609630. 
Laws, E.A., Harrison, W.G., DiTullio, G.R., 1985. A comparison of nitrogen assimilation rates based on ${ }^{15} \mathrm{~N}$ uptake and autrophic protein synthesis. Deep Sea Reseach, 32, 85-95.

Le Corre, P., L’Helguen, S., Wafar, M., 1993. Nitrogen source for uptake by Gyrodinium cf. Aureolum in a tidal front. Limnology and Oceanography, 38, 2, 446-451.

Le Corre, P., Wafar, M.V.M., L’Helguen, S., Maguer, J.F., 1996. Ammonium assimilation and regeneration by fractionated plankton in permanently well-mixed temperate waters. Journal of Plankton Research, 18, 355-370.

Lee, S., Fuhrman, J.A., 1987. Relationships between biovolume and biomass of naturally derived marine bacterioplankton. Applied of Environmental Microbiology, 53, 1298-1303.

Lewis, M.R., Cullen, J.J., Platt, T., 1984. Relationship between vertical mixing and photoadaptation of phytoplankton: similarity criteria. Marine Ecology Progress Series, 15, 141-149.

L’Helguen, S., Madec, C., Le Corre, P., 1996. Nitrogen in permanently well-mixed temperate coastal waters. Estuarine Coastal and Shelf Science, 42, 803-818.

L’Helguen, S., Maguer, J.F., Caradec, J., 2008. Inhibition kinetics of nitrate uptake by ammonium in size-fractionated oceanic phytoplankton communities: implications for new production and f-ratio estimates. Journal of Plankton Research, 30, 10, 1179-1188. 
L’Helguen, S., Slawyk, G., Le Corre, P., 2005. Seasonal patterns of urea regeneration by sizefractionated microheterotrophs in well-mixed temperate coastal waters. Journal Plankton Research, 27, 3, 263-270.

Lim, P.T., Leaw, C.P., Usup, G., 2006. Effect of light and temperature on growth, nitrate uptake, and toxin production of two tropical dinoflagellates: Alexandrium tamiyavanichii and Alexandrium minutum (Dinophyceae). Journal of Phycology, 42, 786-799.

Litchman, E., Klausmeier, C.A., Bossard, P., 2004. Phytoplankton nutrient competition under dynamic light regimes. Limnology and Oceanography, 49, 4, part 2, 1457-1462.

MacIsaac, J.J., Dugdale, R.C., 1972. Interactions of light and inorganic nitrogen in controlling nitrogen uptake in the sea. Deep Sea Research, 19, 209-232.

Maguer, J.F., L’Helguen, S., Madec, C., Le Corre, P., 1998. Uptake and regeneration of nitrogen in the well-mixed waters of the English Channel : new and regenerated productions. Oceanologica Acta, 21, 6, 861-870.

Maguer, J.F., L’Helguen, S., Waeles, M., Morin, P., Riso R., Caradec, J., 2009. Sizefractionated phytoplankton biomass and nitrogen uptake in response to high nutrient load in the North Biscay Bay in Spring. Continental Shelf Research, 29, 1103-1110.

Mead, R., Curnow, R.N., 1983. Statistical methods in agriculture and experimental biology. Chapman and Hall, London, 331 p. 
Moore, C.M., Suggett, D.J., Hickman, A.E., Kim, Y.N., Tweddle, J.F., Sharples, J., Geider, R.J., Holligan, P.M., 2006. Phytoplankton photoacclimation and photoadaptation in response to environmental gradients in a shelf sea. Limnology and Oceanography, 51, 2, 936-949.

Muggli, D.L., Smith Jr, W.O., 1993. Regulation of nitrate and ammonium uptake in the Greenland Sea. Marine Biology, 115, 199-208.

Mulholland, M.R., Ohki, K., Capone, D.G., 1999. Nitrogen utilization and metabolism relative to pattern of $\mathrm{N}_{2}$-fixation in culture of Trichodesmium NIBB1067. Journal of Phycology, 35, 977-988.

Mulholland, M.R., Lomas, M.W., 2008. Nitrogen uptake and assimilation. In : Capone D.G., Bronk D.A., Mulholland M.R., Carpenter E.J. (Eds), Nitrogen in the Marine Environment, $2^{\text {nd }}$ edition, Elsevier, pp 303-384

Paasche, E., Bryceson, L., Tangen, K., 1984. Interspecific variation in dark nitrogen uptake by dinoflagellates. Journal of Phycology, 20, 394-401.

Pennock, J.R., 1987. Temporal and spatial variability in phytoplankton ammonium and nitrate uptake in the Delaware Estuary. Estuarine, Coastal and Shelf Sciences, 24, 841-857.

Platt, T.P., Gallegos, C.L., Harrison, W.G., 1980. Photoinhibition of photosynthesis in natural assemblages of marine phytoplankton. Journal Marine Research, 38, 687-701. 
Potvin, C., Lechowicz, M.J., Tardif, S., 1990. The statistical analysis of Ecophysiological response curves obtained from experiments involving repeated measures. Ecology, 71, 4, $1389-1400$.

Priscu, J.C., 1984. A comparison of nitrogen and carbon metabolism in the shallow and deepwater phytoplankton populations of a subalpine lake: response to photosynthetic photon flux density. Journal of Plankton Research, 6, 733-749.

Priscu, J.C., Lizotte, M.P., Cota, G.F., Palmisano, A.C., Sullivan, C.W., 1991. Comparison of the irradiance response of photosynthesis and nitrogen uptake by sea ice microalgae. Marine Ecology Progress Series, 70, 201-210.

Richardson, K., Beardall, J., Raven, J.A., 1983. Adaptation of unicellular algae to irradiance: a analysis of strategies. New Phytologist. 93, 157-191.

Riegman, R., Stolte, W., Noordeloos, A.A.M., Slezak, D., 2000. Nutrient uptake and alkaline phosphatase (EC 3:1:3:1) activity of Emiliana huxleyi (Prymnesiophyceae) during growth under $\mathrm{N}$ and P limitation in continuous cultures. Journal of Phycology, 36, 87-96.

Rigano, D.M.V., Vona, V., Esposito, S., Di Martino, C., Rigano, C., 1990. Light-dependent decline of $\mathrm{NH}_{4}{ }^{+}$assimilation under $\mathrm{CO}_{2}$ deprivation in N-limited Chlorella sorokiniana (Chlorophyceae). Journal of Phycology, 26, 69-72.

Ryther, J.H., Dunstan, W.M., 1971. Nitrogen, phosphorus and eutrophication in the coastal marine environment. Science, 1971, 1008-1013. 
Slawyk, G., 1979. ${ }^{13} \mathrm{C}$ and ${ }^{15} \mathrm{~N}$ uptake by phytoplankton in the Antarctic uptwelling area: results from the Antiprod I cruise in the Indian Ocean sector. Australian Journal Marine Freshwater Research, 30, 431-448.

Smith, G.J., Zimmerman, R.C., Alberte, R.S., 1992. Molecular and physiological-responses of diatoms to variable levels of irradiance and nitrogen availability - growth of Skeletonema costatum in simulated upwelling conditions. Limnology and Oceanography, 37, 987-1007.

Stolte, W., Riegman, R., 1995. Effect of phytoplankton size on transient-state nitrate and ammonium uptake kinetics. Microbiology, 141, 1221-1229.

Syrett, P.J., 1981. Nitrogen metabolism of microalgae. Canadian Bulletin of Fisheries and Aquatic Sciences, 210, 346, 182-210.

Tremblay, J.E., Legendre, L., Klein, B., Therriault, J.C., 2000. Size-differential uptake of nitrogen and carbon in the a marginal sea (Gulf of St Laurence, Canada). Significiance of diel periodicity and urea uptake. Deep Sea Research II, 47, 489-518.

Wafar, M.V.M., Le Corre, P., Birrien, J.L., 1983. Nutrients and primary production in permanently well-mixed temperate coastal waters. Estuarine, Coastal and Shelf Sciences, 17, 431-446. 
Wafar, M., L’Helguen, S., Raikar, V., Maguer J.F., Le Corre, P., 2004. Nitrogen uptake by size-fractionated plankton in permanently well-mixed temperate coastal waters. Journal of Plankton Research, 26, 10, 1207-1218.

Wilkerson, F.P., Dugdale, R.C., Kudela, R.M., Chavez, F.P., 2000. Biomass and productivity in Monterey Bay, California: contribution of the large phytoplankton. Deep Sea Research II, 47, 1003-1022.

Woods, E.D., Armstrong, F.A.J., Richards, F.A., 1967. Determination of nitrate in sea water by cadmium-copper reduction of nitrite. Limnology and Oceanography, 31, 998-1001. 
Legends of tables and figures

Table 1: Kinetic parameters describing the characteristics of $\mathrm{NH}_{4}{ }^{+}$and $\mathrm{NO}_{3}{ }^{-}$uptake as a function of light and cell size, for the phytoplankton community in the well-mixed waters of the English Channel. The presented values are the means of parameters obtained at the two light depths (50 and $1 \%$ of $\mathrm{I}_{0}$ ) where the phytoplankton samples were collected. Values for maximum $\left(V_{\max }^{\prime}\right)$ and dark $\left(V_{d}\right)$ uptake rates are in units of $\mathrm{h}^{-1}, \%$ inh, which describe the reduction of $\mathrm{N}$ uptake at $100 \%$ of $I_{0}$ expressed as a percentage of total maximum uptake $\left(V^{\prime}{ }_{\text {max }}+V_{d}\right)$. Light indices $\left(K_{L T}\right.$ and $\left.E_{\text {opt }}\right)$ are given in $\mu$ mol photons $\mathrm{m}^{-2} \mathrm{~s}^{-1}$ and as a percentage of incident light intensity (in parentheses). n.d. indicates that parameters could not be generated with the formulation used.

Fig. 1: Seasonal variations of (a) solar radiation; (b) euphotic zone depth (Ze), defined as the depth corresponding to $1 \%$ of surface irradiance; (c) mean light intensity in the water column $\left(I_{m}\right)$; and (d) mean temperature of the water column, at the study station during 2005.

Fig. 2: Seasonal variations of concentrations of $\mathrm{NO}_{3}{ }^{-}$(filled circles) and $\mathrm{NH}_{4}{ }^{+}$(open circles) at the study station during 2005. Because the vertical distribution of the $\mathrm{N}$ nutrient was homogeneous, the data were averaged over the following three depths: $0,20,40 \mathrm{~m}$.

Fig. 3: $\mathrm{NH}_{4}{ }^{+}$uptake rates as a function of light (expressed as a percent of $I_{0}$ ) for $<10 \mu \mathrm{m}$ (circles) and $>10 \mu \mathrm{m}$ (square) size fractions of phytoplankton. Rates were determined in the presence of saturated levels of $\mathrm{NH}_{4}^{+}$. The filled symbols represent the rates collected from a population at $50 \%$ of $I_{0}$, and the open symbols are those collected from a population at $1 \%$ of 
$I_{0}$. Lines are fit iteratively to the data according to the multi-parameter formulation as described in the main text.

Fig. 4: $\mathrm{NO}_{3}{ }^{-}$uptake rates as a function of irradiance (expressed as a percent of $I_{0}$ ) for $<10 \mu \mathrm{m}$ (circles) and >10 $\mu \mathrm{m}$ (square) size fractions of phytoplankton. Rates were determined in the presence of saturated levels of $\mathrm{NO}_{3}{ }^{-}$. The filled symbols represent the rates collected from a population at $50 \%$ of $I_{0}$, and the open symbols are those collected from a population at $1 \%$ of $I_{0}$. Lines are fit iteratively to the data according to the multi-parameter formulation as described in the main text.

Fig. 5: Comparison between the kinetic parameters of $\mathrm{NH}_{4}{ }^{+}$and $\mathrm{NO}_{3}{ }^{-}$uptake for the $<10 \mu \mathrm{m}$ size fraction (a) $V_{\text {max }}^{\prime}$, (b) $V_{d}$, (c) $K_{L T}$, and (d) $E_{\text {opt. }}$ Values for $V_{\text {max }}$ and $V_{d}$ are in units of $\mathrm{h}^{-1}$, and $K_{L T}$ and $E_{\text {opt }}$ are in units of $\mu \mathrm{mol}$ photons $\mathrm{m}^{-2} \mathrm{~s}^{-1}$. Presented data are the mean of the kinetic parameters at $50 \%$ and $1 \%$ of $I_{0}$. Horizontal and vertical bars represent the standard deviation. The solid lines represent the $1 / 1$ ratio.

Fig. 6: Comparison between the kinetic parameters of $\mathrm{NH}_{4}{ }^{+}$and $\mathrm{NO}_{3}{ }^{-}$uptake for the $>10 \mu \mathrm{m}$ size fraction (a) $V^{\prime}{ }_{\max }$, (b) $V_{d}$, (c) $K_{L T}$, and (d) $E_{\text {opt. }}$ Values for $V^{\prime}{ }_{\max }$ and $\mathrm{V}_{d}$ are in units of $\mathrm{h}^{-1}$, and $K_{L T}$ and $E_{\text {opt }}$ are in units of $\mu \mathrm{mol}$ photons $\mathrm{m}^{-2} \mathrm{~s}^{-1}$. Presented data are the mean of kinetic parameters at $50 \%$ and $1 \%$ of $I_{0}$. Horizontal and vertical bars represent the standard deviation. The solid lines represent the $1 / 1$ ratio.

Fig. 7: Comparison between the mean light available to the cells $\left(I_{m}\right)$ and the light needed to reach the maximal $\mathrm{N}$ uptake $\left(E_{\text {opt }}\right.$ ), when (a) $\mathrm{NH}_{4}{ }^{+}$and (b) $\mathrm{NO}_{3}{ }^{-}$was the $\mathrm{N}$ substrate. The filled symbols represent data for the $<10 \mu \mathrm{m}$ size fraction, and the open symbols those for the 
$>10 \mu \mathrm{m}$ size fraction. The $E_{\text {opt }}$ values are the means of values obtained at $50 \%$ and $1 \%$ of $I_{0}$. Vertical bars represent the standard deviation. The solid lines represent the 1/1 ratio.

Fig. 8: Comparison between the $\mathrm{N}$ uptake rates at $I_{m}\left(V_{I m}\right)$ and the total $\mathrm{N}$ uptake at $E_{\text {opt }}\left(V_{\text {max }}\right)$ when (a) $\mathrm{NH}_{4}{ }^{+}$and (b) $\mathrm{NO}_{3}{ }^{-}$was the $\mathrm{N}$ substrate. The filled symbols represent data for the $<10 \mu \mathrm{m}$ size fraction, and the open symbols those for the $>10 \mu \mathrm{m}$ size fraction. Presented data are the mean of parameters at $50 \%$ and $1 \%$ of $I_{0}$. Horizontal and vertical bars represent the standard deviation. The solid lines represent the $1 / 1$ ratio.

Fig. 9: Comparison between the $\mathrm{NO}_{3}{ }^{-}$and $\mathrm{NH}_{4}{ }^{+}$uptake rates at $I_{m}$. The filled symbols represent data for the $<10 \mu \mathrm{m}$ size fraction, and the open symbols those for the $>10 \mu \mathrm{m}$ size fraction. Presented data are the mean of $V_{I m}$ at $50 \%$ and $1 \%$ of $I_{0}$. Horizontal and vertical bars represent the standard deviation. The solid line represents the 1/1 ratio.

Fig. 10: Comparison between the $\mathrm{N}$ uptake rates in $<10 \mu \mathrm{m}$ and in $>10 \mu \mathrm{m}$ size fractions at $I_{m}$. The filled symbols represent data where $\mathrm{NO}_{3}{ }^{-}$was the $\mathrm{N}$ substrate, and the open symbols those where $\mathrm{NH}_{4}{ }^{+}$was the $\mathrm{N}$ substrate. Presented data are the mean of $V_{\text {Im }}$ at $50 \%$ and $1 \%$ of $I_{0}$. Horizontal and vertical bars represent the standard deviation. The solid line represents the 1/1 ratio 

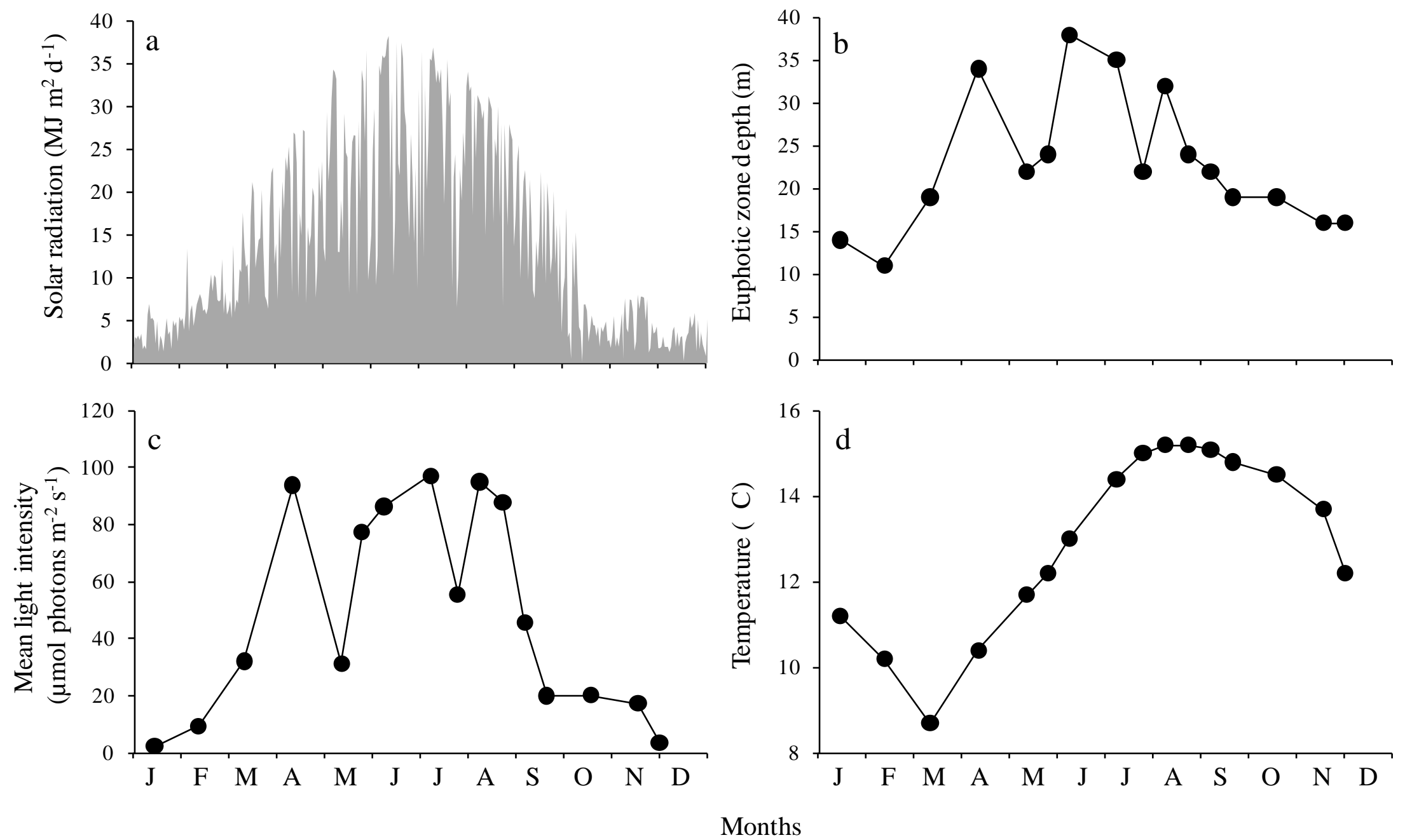

Maguer et al.,FIG. 1 


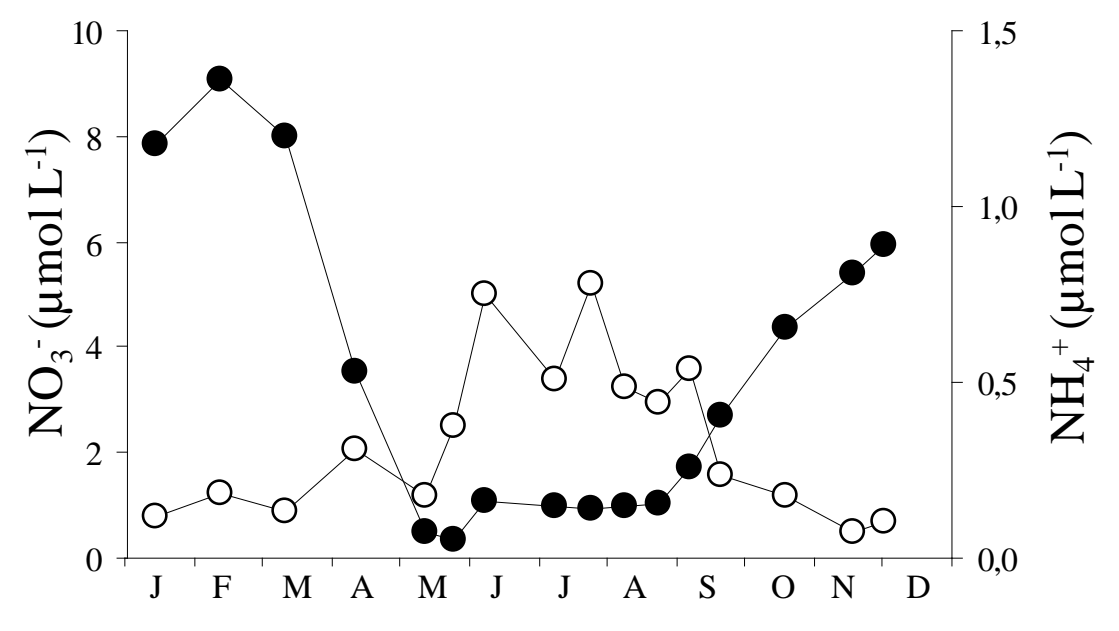

Months

Maguer et al., FIG. 2 

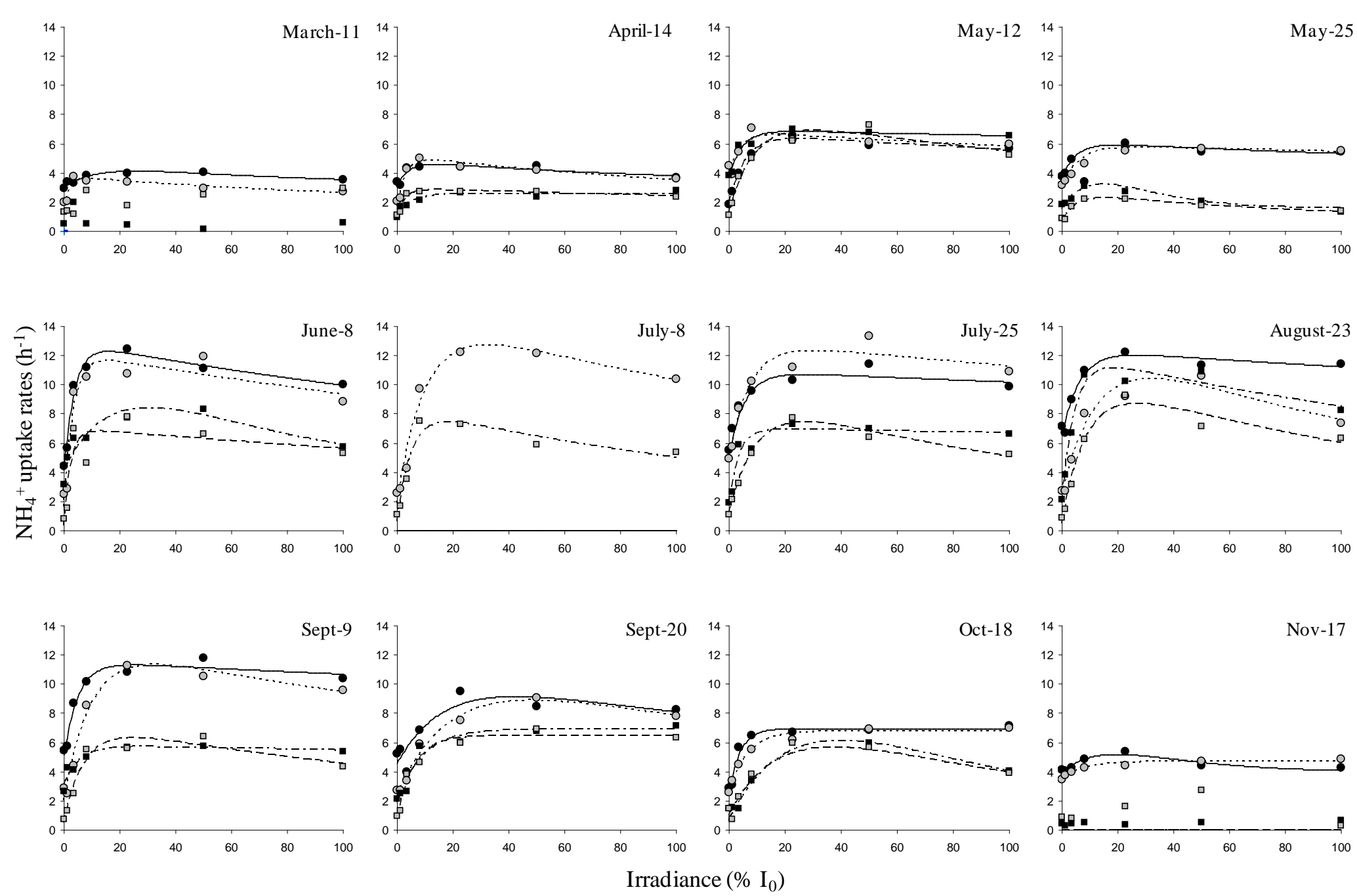

Maguer et al., FIG. 3 

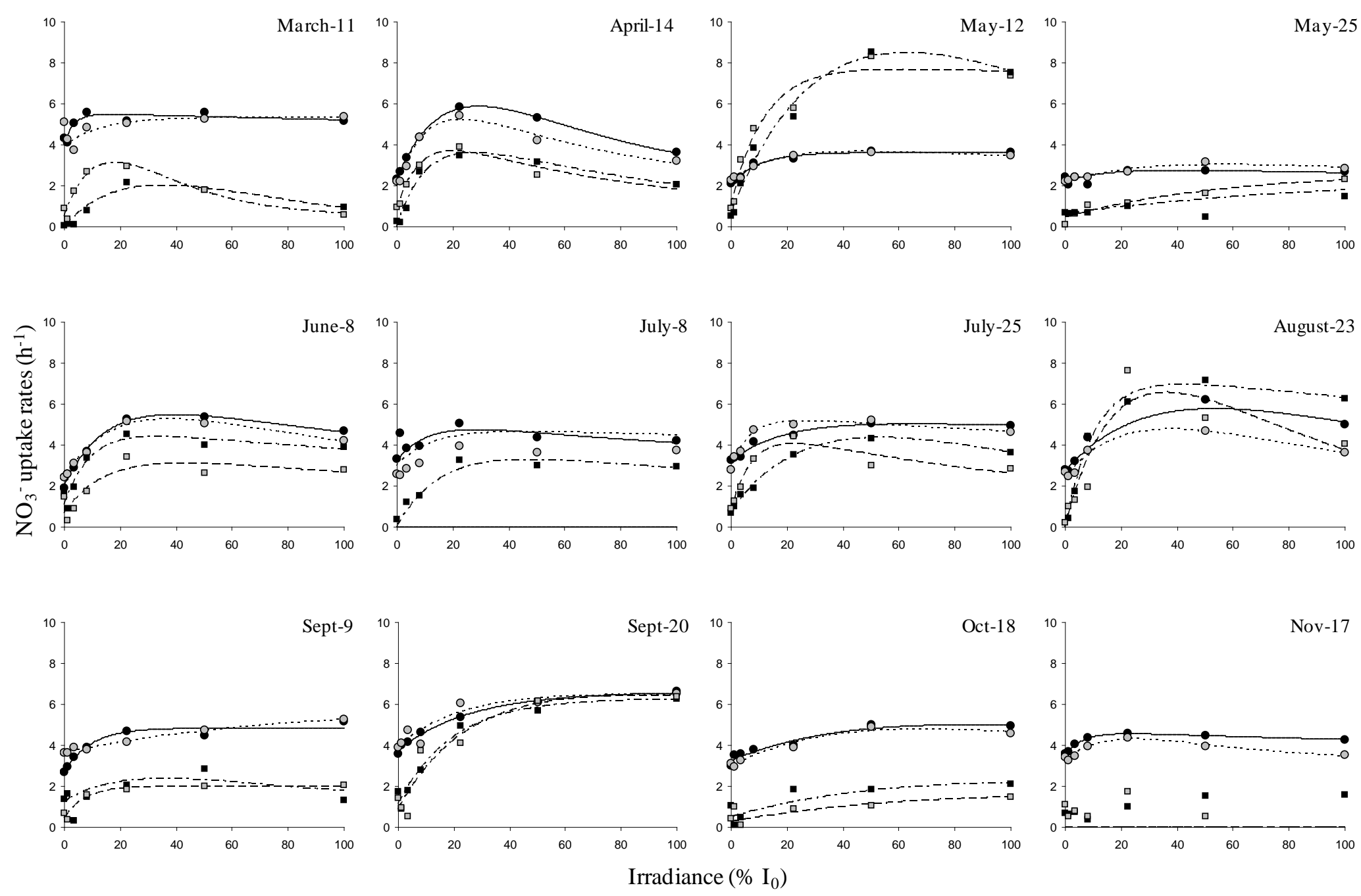

Maguer et al., FIG. 4 


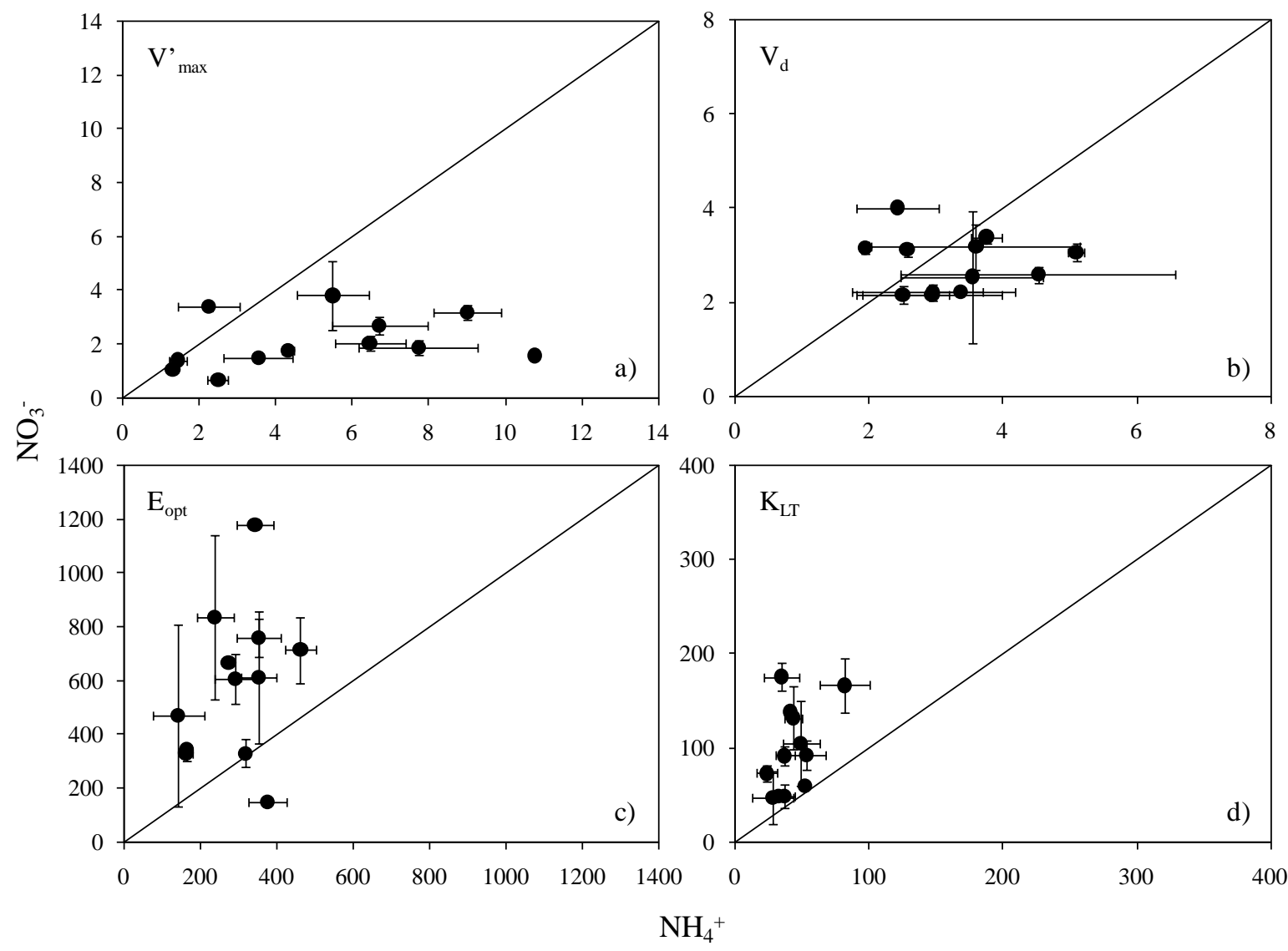

Maguer et al., FIG. 5 


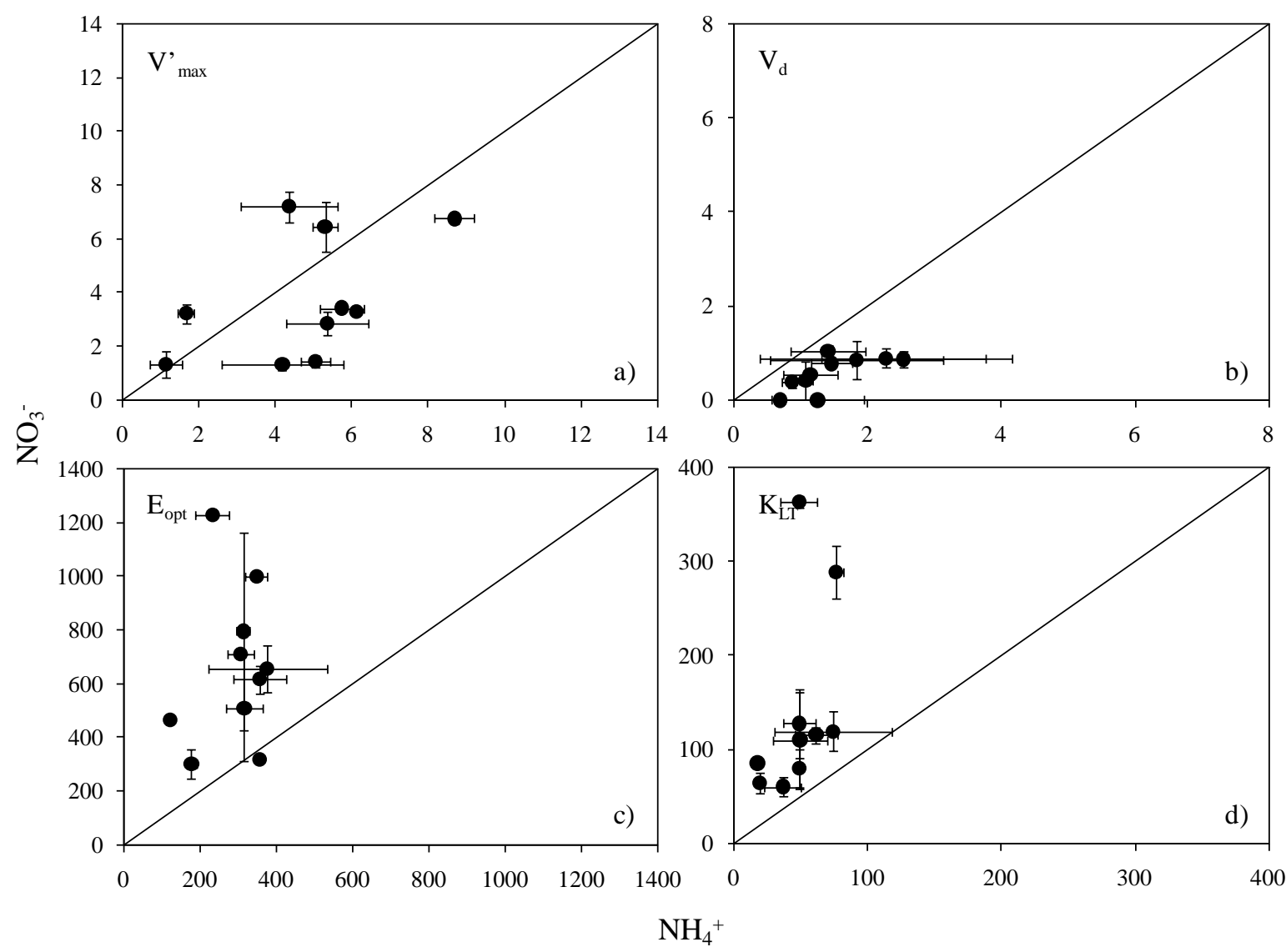

Maguer et al., FIG. 6 


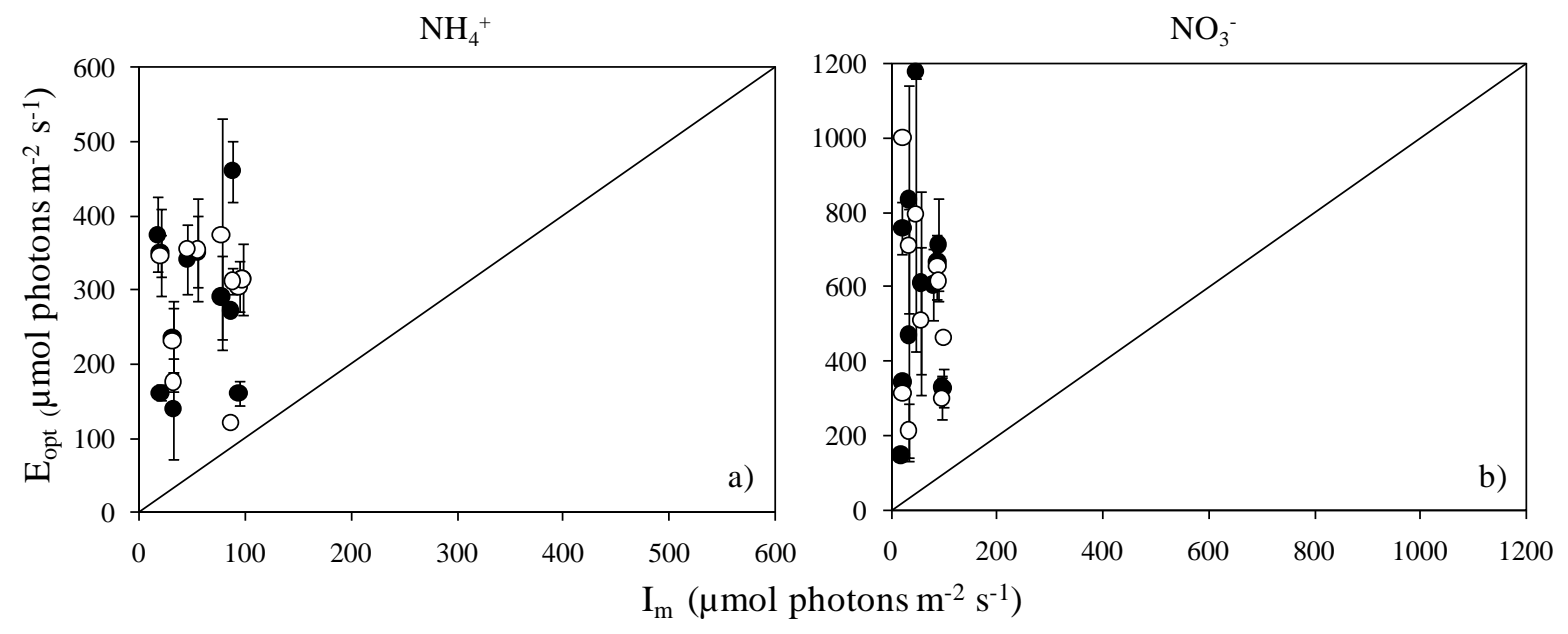

Maguer et al., FIG. 7 


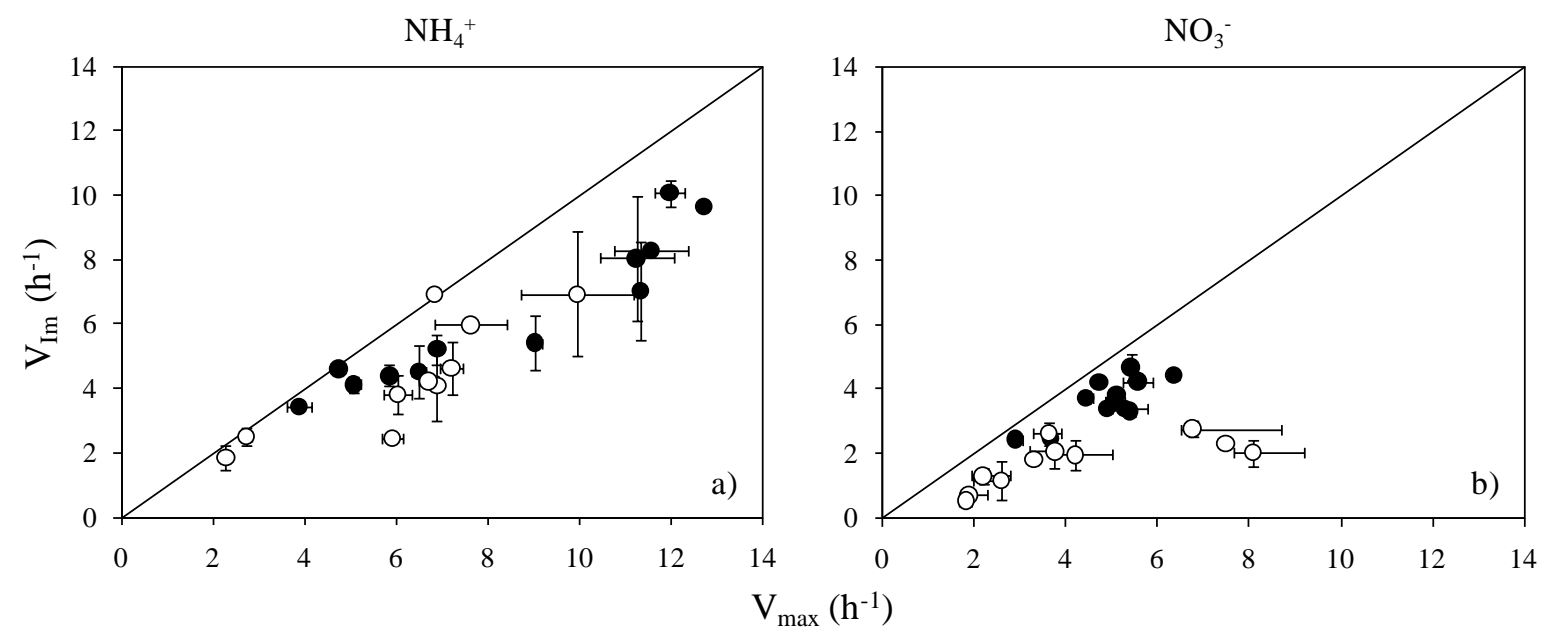

Maguer et al., FIG. 8 


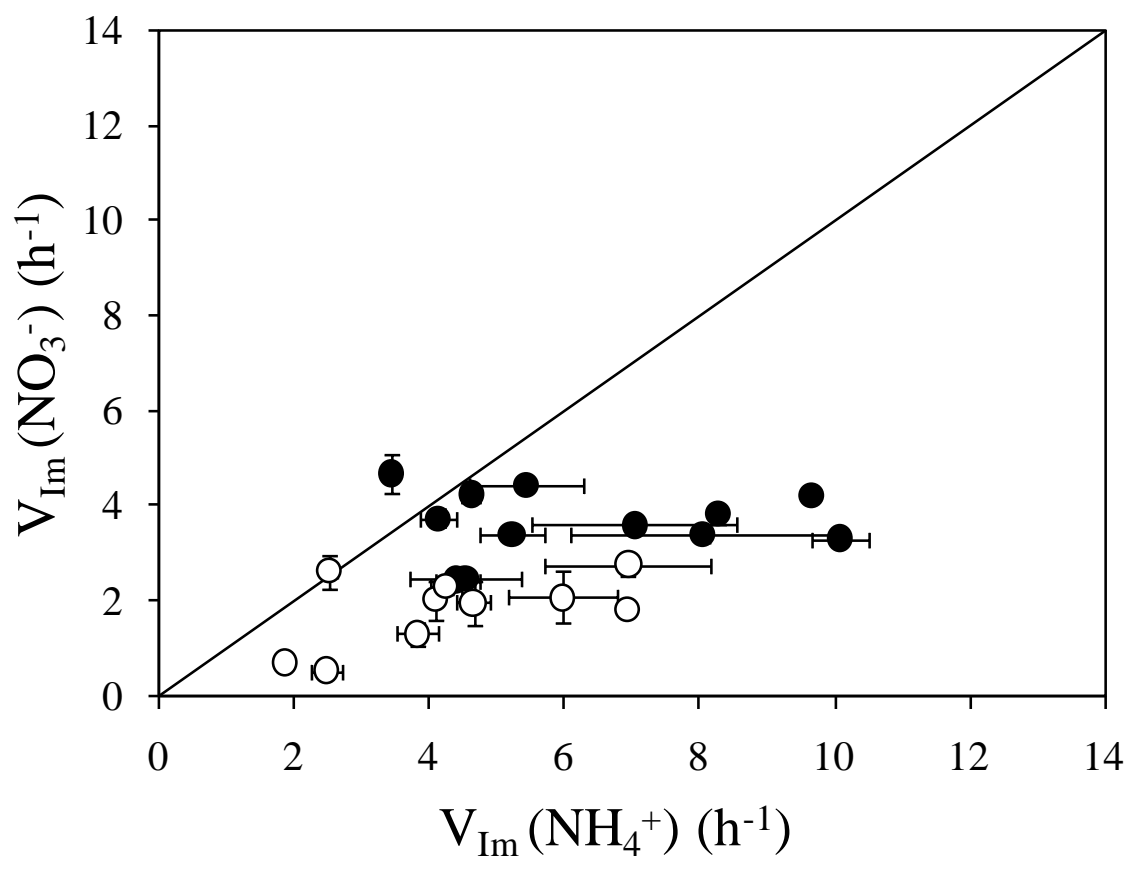

Maguer et al., FIG. 9 


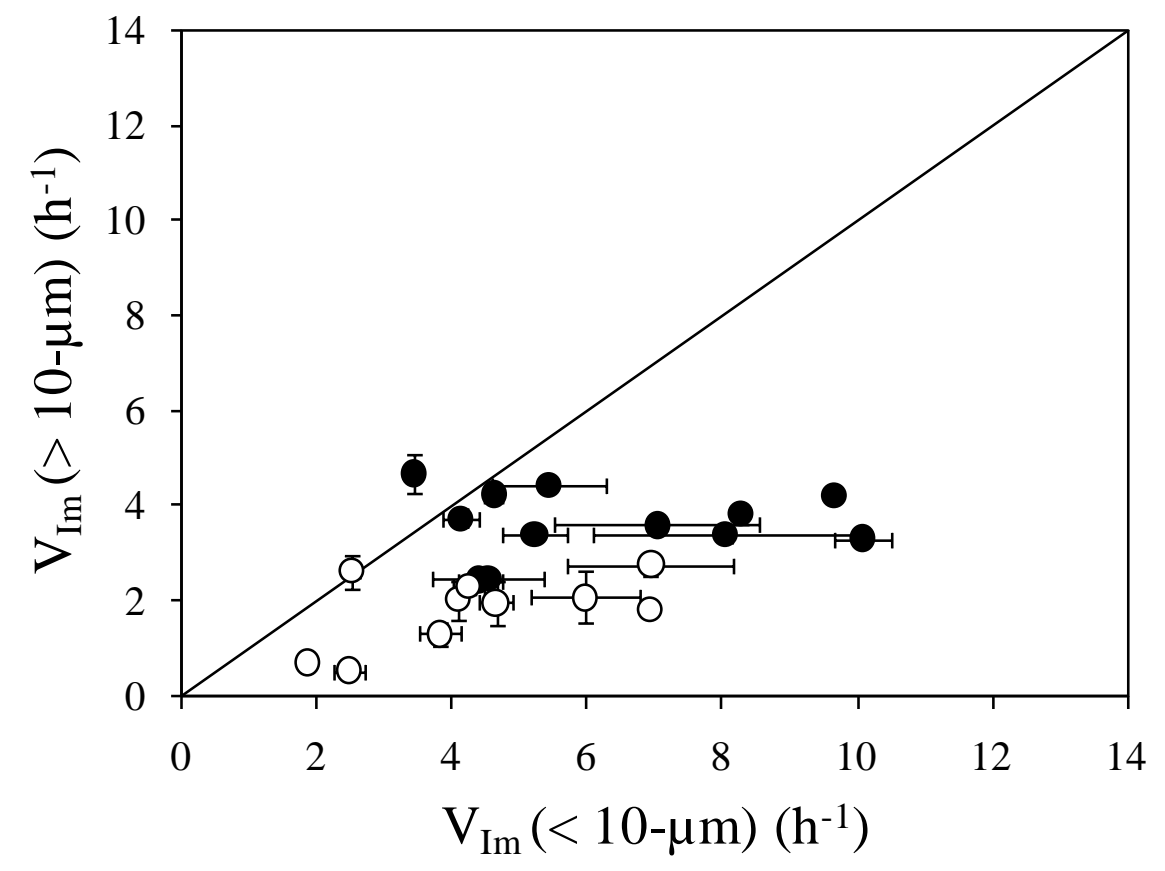

Maguer et al., FIG. 10 
